\title{
Reusing and Recycling Strategies in Designing the Costume for the Theater between Kuwait and the UK
}

\author{
Ali Bin Hussain \\ The Higher Institute of Dramatic of Arts Kuwait, Kuwait City, Kuwait \\ Email: ostn_ostn@hotmail.com
}

How to cite this paper: Hussain, A. B. (2021) Reusing and Recycling Strategies in Designing the Costume for the Theater between Kuwait and the UK. Low Carbon Economy, 12, 73-116.

https://doi.org/10.4236/lce.2021.123005

Received: July 15, 2021

Accepted: September 4, 2021

Published: September 7, 2021

Copyright ( 2021 by author(s) and Scientific Research Publishing Inc. This work is licensed under the Creative Commons Attribution International License (CC BY 4.0).

http://creativecommons.org/licenses/by/4.0/

\section{(c) (i) Open Access}

\begin{abstract}
Reusing and recycling materials inside the domains of showy ensemble plan and generation is critical. When a Kuwaiti play wraps up its run, ensembles are tossed absent and modern ones are outlined when vital. This hone demonstrates a need for mindfulness of reusing procedures. This is often a genuine matter; tons of material materials are being squandered instead of reused. The current preparation of creating ensembles for Kuwait theatre preparations includes the conception and portraying of ensembles, the buy of modern textures, and the work of tailors for a generation. Since fitting is outsourced, there's a deficiency of architects who can make outfits independently. The current handle does not consolidate any strategies for reusing ensembles. This combined with tall levels of material squander, comes about in critical biological issues that request quick consideration. However, in countries such as Kuwait, where the hone was commonplace earlier to the Iraqi intrusion, this can be not the case. This qualitative study looked for examining current hones among Kuwaiti costumiers and after that compared these to UK costumiers who give an illustration of existing feasible (reusing and recycling) ensemble plan hones. It pointed to explore the states of mind and discernment of Kuwaiti costumiers towards reusing and reusing as ways of lessening material squander. This paper used exploratory and participatory modes of essential investigation. Thinks were conducted to assemble essential information, an arrangement of semi-structured interviews was conducted with $4 \mathrm{UK}$ and 4 Kuwaiti costumiers to inspire data on understanding their sustainable design process into making costumes. This paper will survey the discoveries of investigating ventures and exploring the generation forms utilized by ensemble originators within the UK and Kuwait. It'll demonstrate how the Kuwaiti costumers their behaviors, coupled with their need of know-
\end{abstract}


ledge with utilizing reusing and reusing methodologies to make ensembles, had expanded material squander and adversely influenced the Kuwait theater ensemble plan industry.

\section{Keywords}

Reuse, Recycle, Upcycle, Sustainability, Textiles Waste

\section{Introduction}

In this paper, I will give a model case ponder report finding to demonstrate the activity investigate handle, which was commonplace of all cases of the method to make costumes in situ. This paper describes in-depth the observation activities in Kuwait centred on four Kuwaiti costume designers during the Kuwait Theatre Festival, with the observed four costume designers in the UK. When interviewing the costume designers in the UK on their site and their costume design work on their studios site. In detail, this paper demonstrates the findings result of the Kuwaiti and UK costume designers to create the costumes collection for each different project and play, the purpose of my observation, to present a design methodology, centred around reuse and recycling, which Kuwaiti costume designers can use as working guidelines with which to optimise sustainable practice in theatrical production, which were practical experiments of the reusing and recycling production costumes and textiles different materials and methods to present the costume collection on the stage both in the UK and Kuwait costume design industry.

The case studies are classified in this paper and presented according to the type of input material. The different types of textiles waste were used as input material in theatre costume design costume designer's technique, unique, one-off collections and both for small- and large-scale production. This division highlights and gives an overview of the problems of the Kuwaiti costume designer comparing with skills of producing costume with UK costumes designers. Collective case thinks about contrast from solitary cases, which center on the in-depth cataloging of specific cases or issues. This approach is most suited to this subjective phenomenological investigation which has an intrigued in a specific case or centers on the way specific occasions and intelligence impact circumstances or settings. Be that as it may, within another area will illustrate the Kuwaiti outfit designers prepare, abilities, procedure and generation in making outfits and selecting outfit materials for a play appear, for each distinctive venture and plays in Kuwait costume design theater industry, within the following segment.

\section{The significance of the study}

Reducing waste, reusing discarded items (in this situation clothes and costumes) and recycling substances (in this example textiles) isn't always the most effective and environmentally pleasant practice (Blackburn, 2009; Payne, 2011), 
it's also economically high-quality because it permits humans to get extra use out of a product in addition to lowering the want to shop for new substances while growing something new (Blackburn, 2009; Andersen \& Earley, 2014).

Because of this, many human beings in western countries, inclusive of style designers and dressmakers for theatrical and different productions, have interaction with inside the exercise of sustainable dress layout along with reusing and recycling garments and materials (Gwilt \& Rissanen, 2011; Gwilt, 2014). However, Kuwait is specifically noteworthy for now no longer adopting this exercise, as there isn't always handiest a dearth of studies on sustainable dress layout withinside the country, the small number of studies that does exist shows nearly no designers exercise it (Naseem, 2013).

This is evident to the factor wherein asking a tailor or a person withinside the garb marketplace approximately reuse and recycling will elicit the simplest confusion (Naseem, 2013). Although the reuse or as a minimum the recycling of textiles isn't completely unknown withinside the country (Al-Arfaj Group, 2015), my studies at the theatre area mainly indicated that now no longer simplest is sustainable dress layout now no longer practiced, it's far absolutely unknown to each designer and tailor (Al-Ghareb, 2001; Al-Wgyan, 2010).

Given the essential position performed with the aid of using designers in shaping dress layout culture, the correlation among the extent of notion given to reuse and recycling, the quantity of reuse and recycling happening in theatre settings as a whole (Andersen \& Earley, 2014), this involved me. When I checked out the state of affairs via the prism of the garment lifecycle, which accommodates the fibre level, fabric production, distribution, retail, use phase, reuse/recycling phase, and the so-referred to as grave phase (Payne, 2011), the reuse/recycling level seems to be absolutely absent, now no longer simply from the practices of Kuwaiti dress designers however additionally as an idea inside Kuwaiti theatres.

This brought about me to analyze the problem very well withinside the hopes of as a minimum locating out whether or not this has usually been the case in Kuwait or sustainable practices used to exist withinside the beyond however had in some unspecified time in the future disappeared. What I observed brought about me to pursue the general aim of this study, that's to introduce the idea of sustainability (reusing and recycling) into the Kuwaiti public cognizance and, extra specifically, into the exercise of Kuwaiti theatre gown designers.

Through these, I explored the variations among Kuwaiti layout and the Western world (represented with the aid of using the UK) and supplied critiques and guidelines on how sustainable design can be brought in Kuwait. In this research paper, I will present the two phases of findings from the semi-structured interviews conducted with both UK and Kuwait costume designers. These elicited information on the practices they adopted and their opinions on these. A comparative approach was adopted, comparing the reuse and recycling strategies utilised in both countries. This included exploring the design process and the participants' views on sustainability practices. In the first phase, I will 
present the Kuwaiti costumes designers' practices in making costumes.

\section{Case Study 1: Kuwaiti Costume Designers}

\subsection{Play 1: Mores Clock: Background}

In Theatre Summer Festival in 2016 relates to one of the main aims of this investigation of the Kuwaiti costume designer production process. The research aims directed to observe several designers in Kuwait while they were in the process of creating a costume for a play, leading to find and explorer more visual evidence recourses from their work and to discover their different skills and technique of using and reusing the costume textiles materials. However let's start to introduce the first Kuwaiti costume designers (B.M.) which he is the costume designer for the play, (see Figure 1 and Table 1), I observed the costumes (Costume designer) during his process of creating a costume for the play when he was creating the costume sketches, up to the final stages of tailoring.

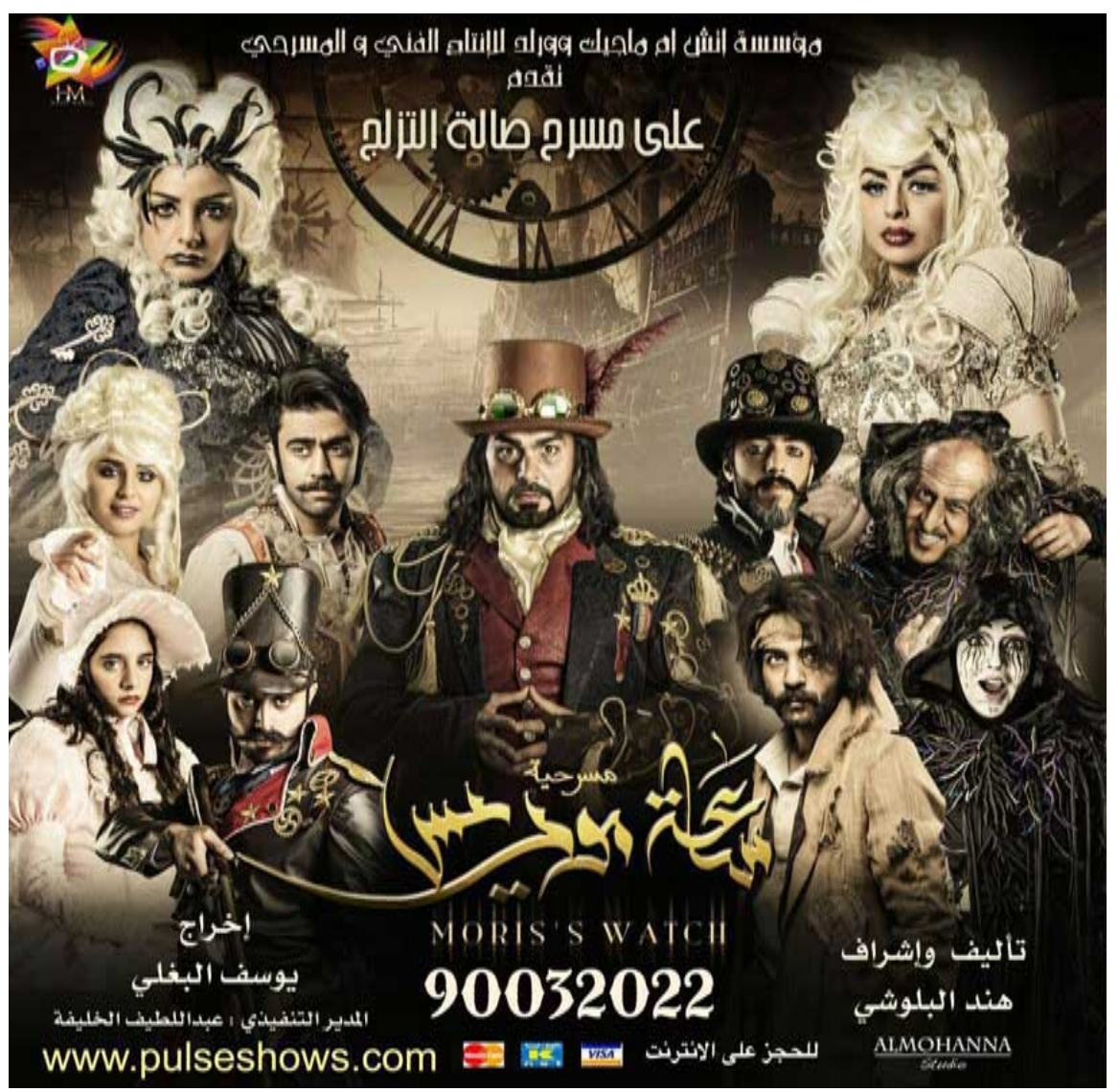

Figure 1. Mores clock play poster (source by author).

Table 1. Details of the play project.

\begin{tabular}{ccc}
\hline Site & Play name & Data Collector \\
\hline The costume designer tailor/studio & Mores Clock & Author \\
\hline
\end{tabular}




\subsection{Design and Crating Customs}

At the site studio I was very surprised from a variety of thick rich costume and textiles for the (Mores play) project production (see Figure 2 and Figure 3). However as it is the goal is to discover the costume designer process of design

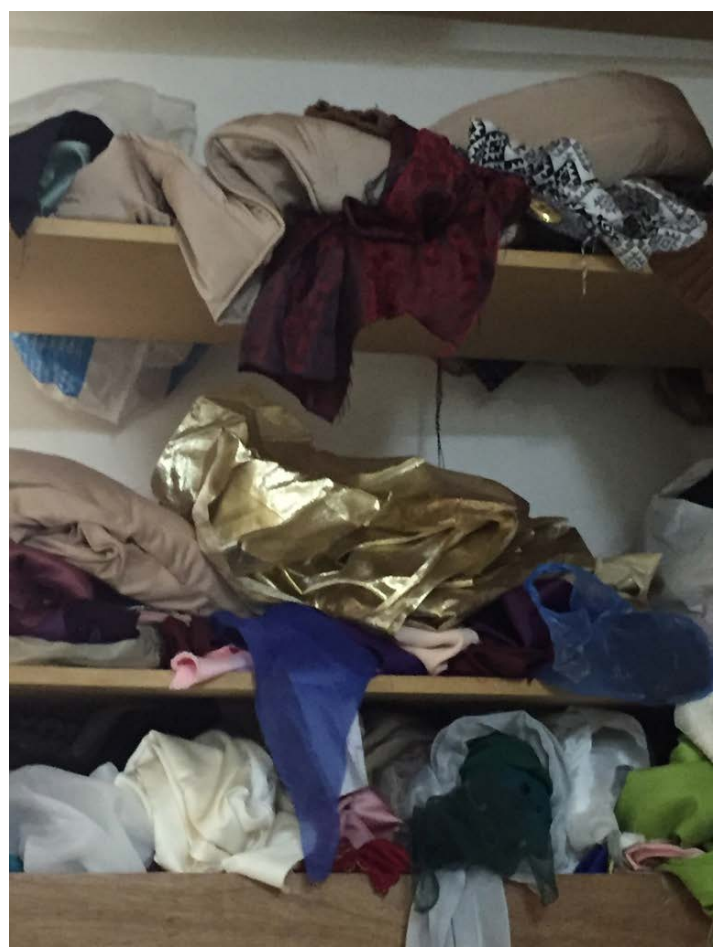

Figure 2. Expensive new fabrics lefts (source by author).

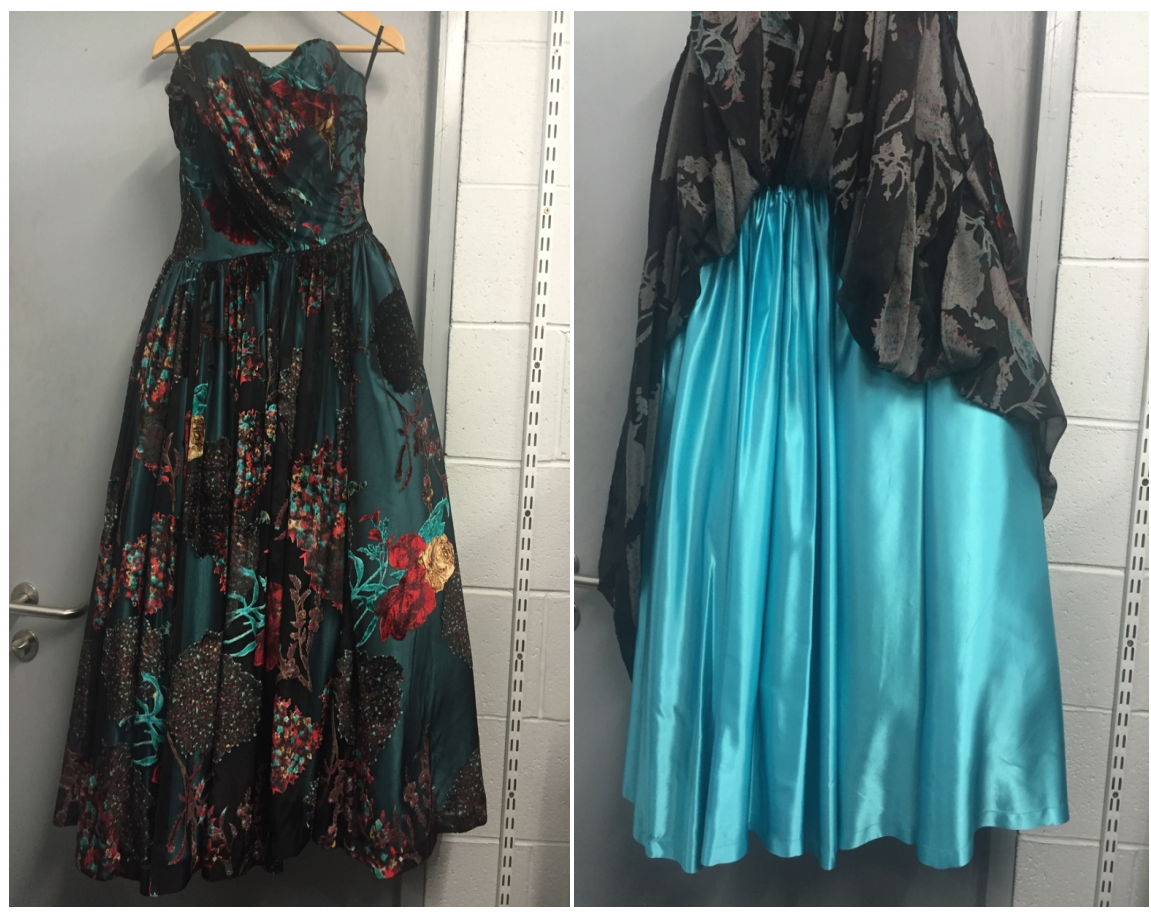

Figure 3. Different costumes for various characters from the Mores paly (source by author). 
and crating costume, for any new plays for every times or did the designer using any reusing and recycle costumes or textiles materials for another play the costume designer (B.M) comment) "I purchase all fabrics or material 2) all the fabrics are new for any new projects or plays 3) My duty is as costume designer reading the script then is to sketching the costume (see Figure 4), up to final look on the stage" (see Figure 5).

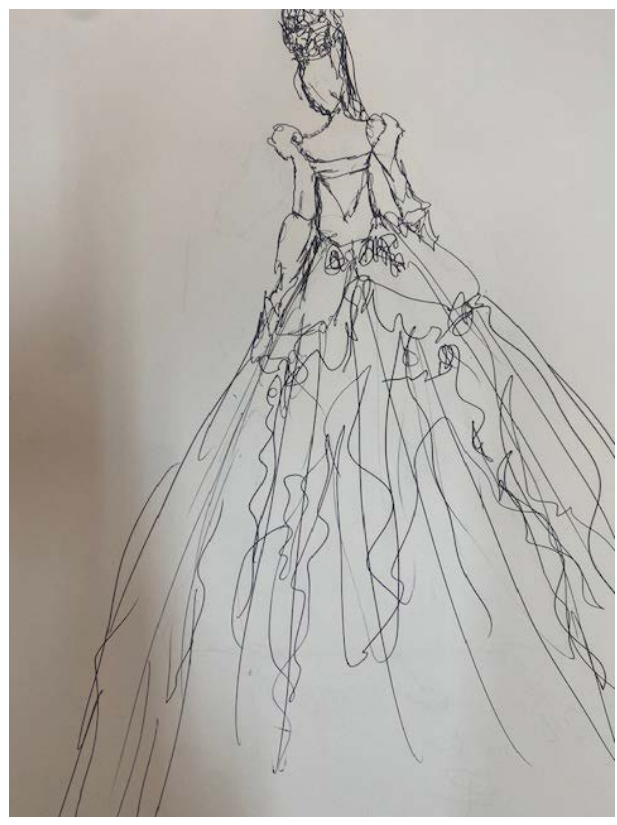

Figure 4. A sketch for characters (source by author).

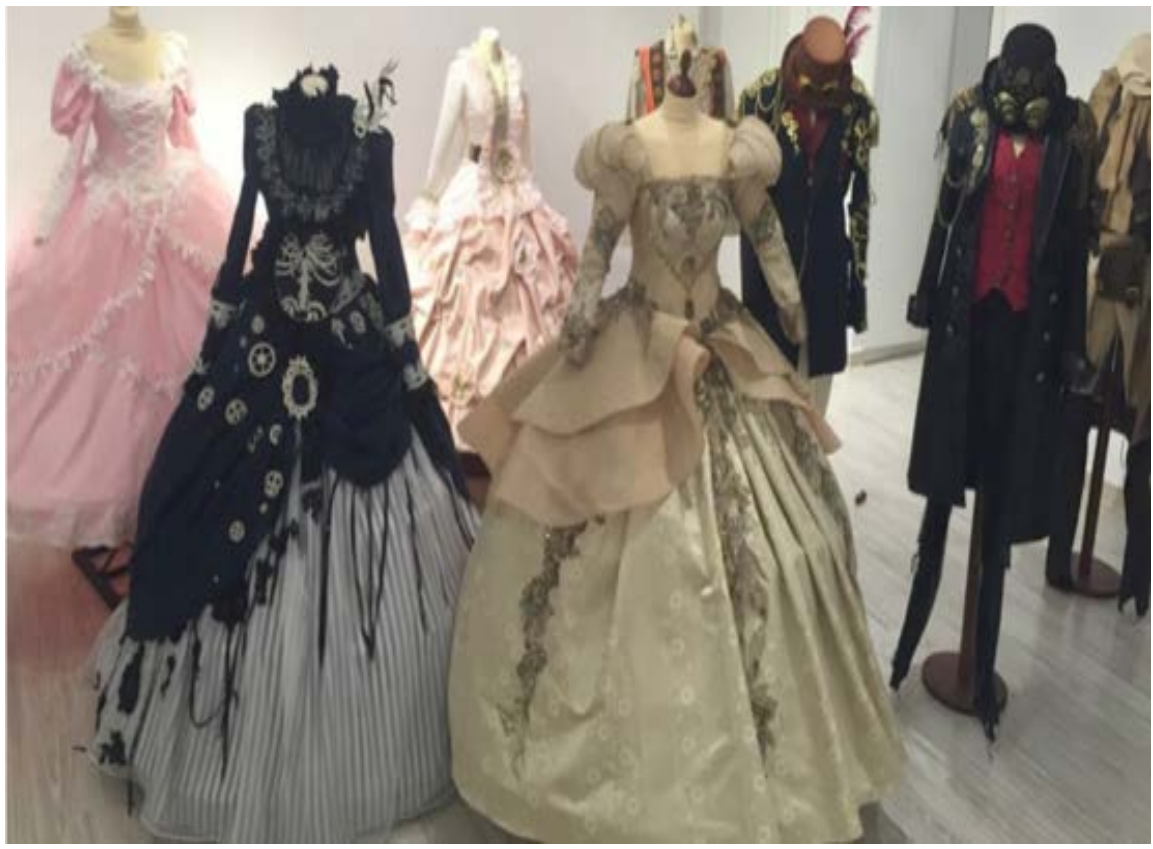

Figure 5. The final look of a variety of different characters in the Mores Clock play. All the fabrics are new, nothing has been recycled or reused from another play (source by author). 


\subsection{Expensive Costume and Materials}

In the costume designer site (tailor studio) I searched for any alternative reuse and recycling costume or textiles materials in his process of creating all the costume collection for this particular play (Mores clock). I asked the designer about from where bring all those rich costume fabrics, which some of fabrics for this play they are looking very expensive and rich textures which is to use for the (fashion occasion haute couture dress) and it's not for using for the costume theater because they are too heavy for the character movement (see Figure 6) According to (Clancy, 2014), "The Costumier must attempt to deliver outfits which show up true on the organize but which are moreover versatile commonsense to wear, fast to alter and ease of development must be obliged". However the designer (B.M) comments "all the fabrics they are new I bought them from the textures showcase in Kuwait, all the textures with a few ensembles embellishments costs me around in Kuwait cash (1.700 Kuwaiti dinar)" which is in UK money around $4000 £$.

In addition, I was draw attention about the rich of costume accessories in his studio site, wondering are those accessories are reused from another play or it was recycling them (see Figure 7) the costume designer (B.M) comment "I bought them from the textile market, there was a shop their sale all the fashion accessories some I found those are related for the play concept for the costumes to shop the costume their identity by using the key objects above for some costumes and then the tailor staff the will sowing all the costume with adding all

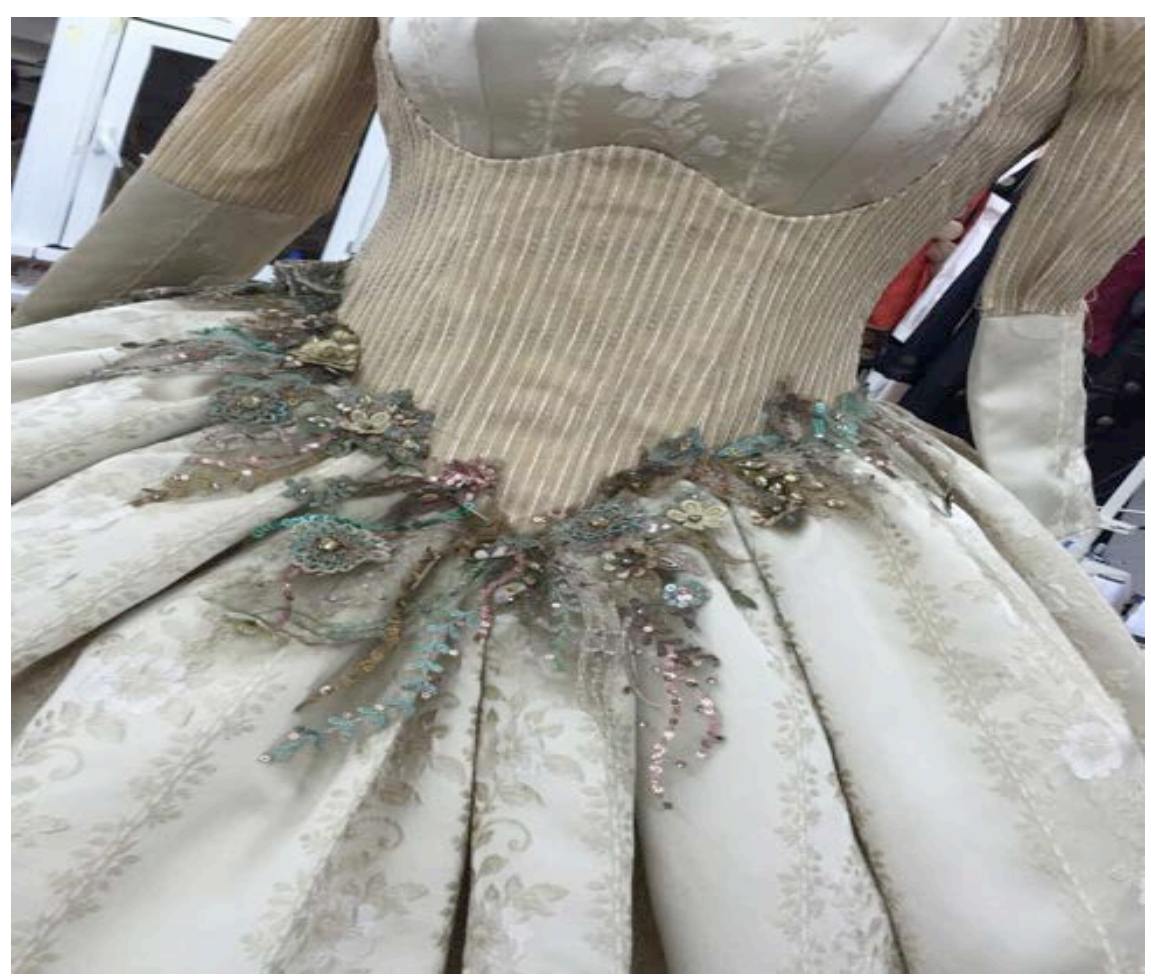

Figure 6. Expensive rich fabrics from the Kuwait textiles market show in the costume in final stage (source by author). 

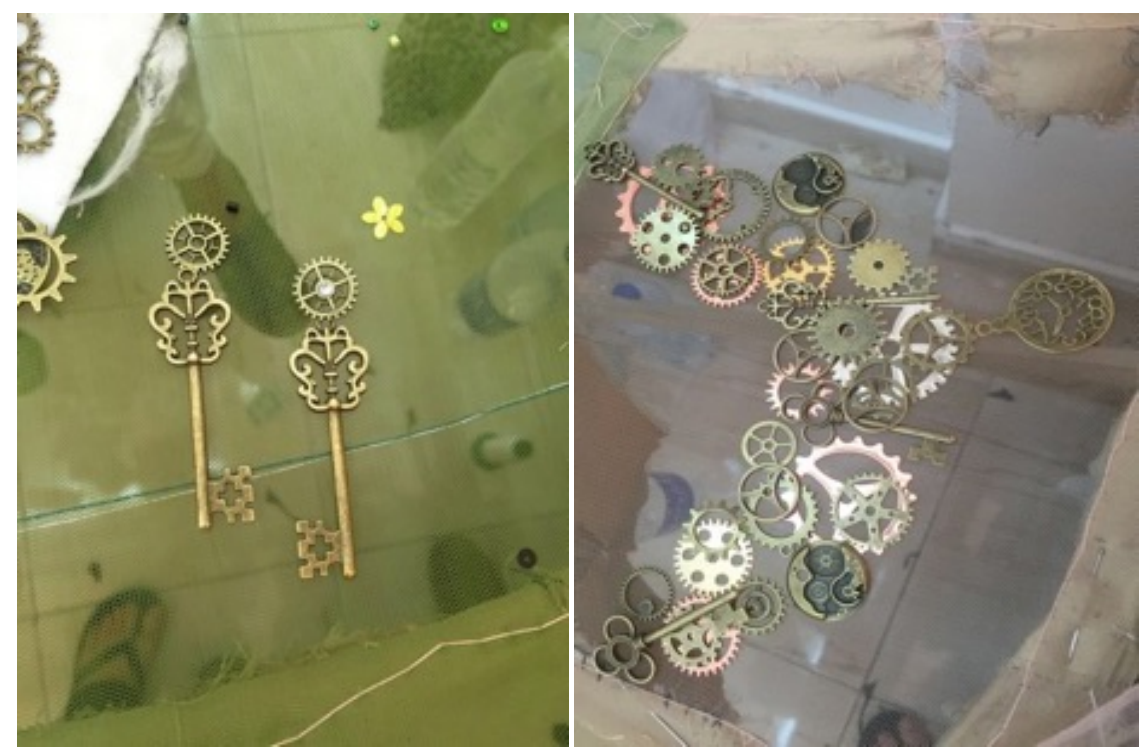

Figure 7. The tailoring staff when they are adding the new costume accessories above one of the play costume character (source by author).

costume accessories". In addition from during the discussion with the costume designer, I figure that the designer use his hand technique just for drawing (sketches) the costume in the paper but, (B.M) never used before his hand skills technique before to cut the fabrics or shredded them in different pieces, or die the fabrics or did any costume construction for old costume or sowing costume for any play.

\subsection{Summary}

During the observation activities was discovered that a lot of the costumes and textiles in (B.M) (studio/tailor) could be reused and recycle and to using different alternative techniques to saving the costume and to reuse and recycling them for another play Thus, this investigation and findings confirmed that there are a lot of costume textiles materials are wasted and must be reused and recycle. However, the next play is traditional fantasy Kuwait play lets discover the process of design and crating this all costumes from a Kuwaiti costume designer perspective.

\section{Play 2 Al_HUKEM LEKM}

\subsection{Background}

Al_HUKEM LEKM it's a Kuwaiti traditional fantasy play, gathering most of all the, Kuwaiti traditional costumes actor and actress in different ages and area in Kuwait in this play. From the poster of this play (see Figure 8 and Table 2) we can see that's this are a variety of different costumes and textiles are used for this play. But the question is are they reused or recycle from another play? Are the costume designers using any sustainable practice methods to produce this costume for the theater production? Did the costume designer use any sustainable 


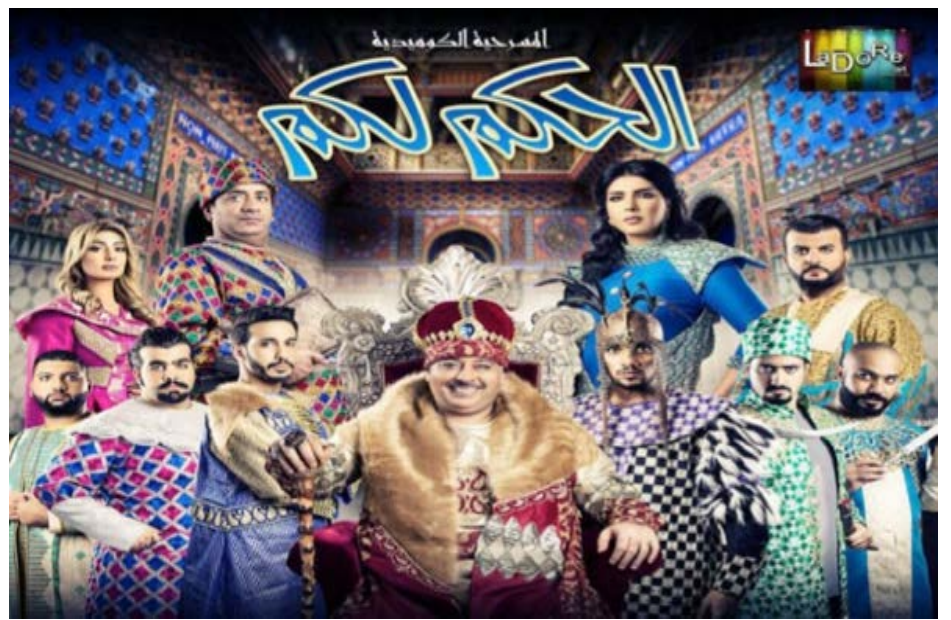

Figure 8. Al_HUKEM LEKM Poster shows variety of different costumes and textiles fabrics (source by author).

Table 2. Details of the play project.

\begin{tabular}{ccc}
\hline Site & Play name & Data Collector \\
\hline Tailor Studio & Al_HUKEM LEKM & Author \\
\hline
\end{tabular}

practice process methods to be producing all these costumes? According to (AlGhareb, 1988), the author of the book Theatrical Movement in Kuwait comment "Kuwait is the most popular country in the gulf country area are, producing a variety of different Kuwaiti traditional plays since 1940 until now day". Which this means that there are much of opportunity for the Kuwaiti costume designers to Reus and recycling costumes for another play, so let's discover the answering this question when I observed this costume designer in the site (tailor studio).

\subsection{Sowing the Costumes by Tailors}

The costume designer for this play (H.D) are working at the most popular theater production company in Kuwait, whom they are producing during the year many and different theater production, hence from here It's was very exciting to know about the process of producing costumes in this company or maybe (H.D) are reused and recycling the costume for another play). However during the informal conversation with costume designer for about his process of producing the costume for this play the designer comment "from my experience in costume design comment, 1) I always reading the script first; 2) then I looked for the actor and actress sizes to know which kind of textiles fabrics that I will use to purchase from Kuwait textiles market, 3) drawing the sketches (see Figure 9); 4) the last process the tailors staff will sowing all the costume up to the final stage (see Figure 10).

\subsection{Wasted Textiles}

Observing the costume designer technique and the costume designer practice 


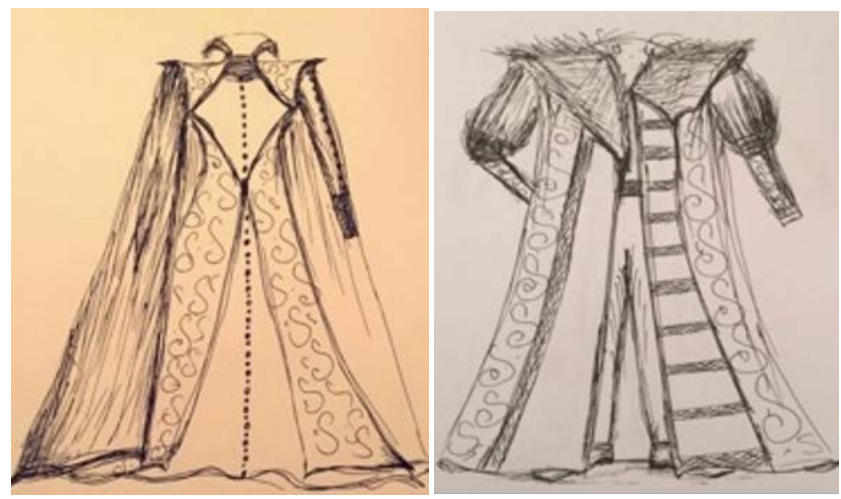

Figure 9. Different sketches of different characters (source by author).

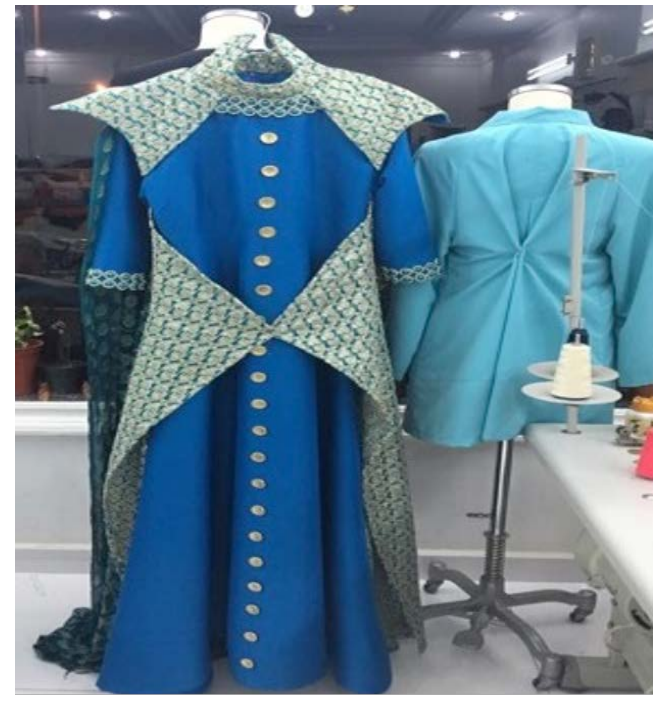

Figure 10. The final look of a new costume at the tailors. Nothing has been reused or recycled (textiles and costumes) from another play (source by author).

design was the most important things in my observation, which to discover if the costume designer is using any used textiles materials and costume contraction methods, or a used costumes for this play for the any characters. However during the observation founded that the costume designer, did not use any used or old costume or textiles fabrics for the play (see Figure 11) all of them are new from the Kuwait textiles market, and when asked him about the reason of did not use used or old costumes a used textiles fabrics, the designer (H.D) comments "Because each costume designer in Kuwait want to show anew costume in the stage every time, I cannot using old costume for any new play". Her answer intentioned contained about the costume construction method, the reason of not using the costume constriction methods (reusing/recycling) and the costume for another play or projects.

The costume designer comment "actually I hear about this process before and I don't know how I can do it or using the constriction costume method, it's hard for me to explaining for the tailors that I want to shredded costume and recycled it again for another play, it's easier for me to buy new textiles fabrics for any new 


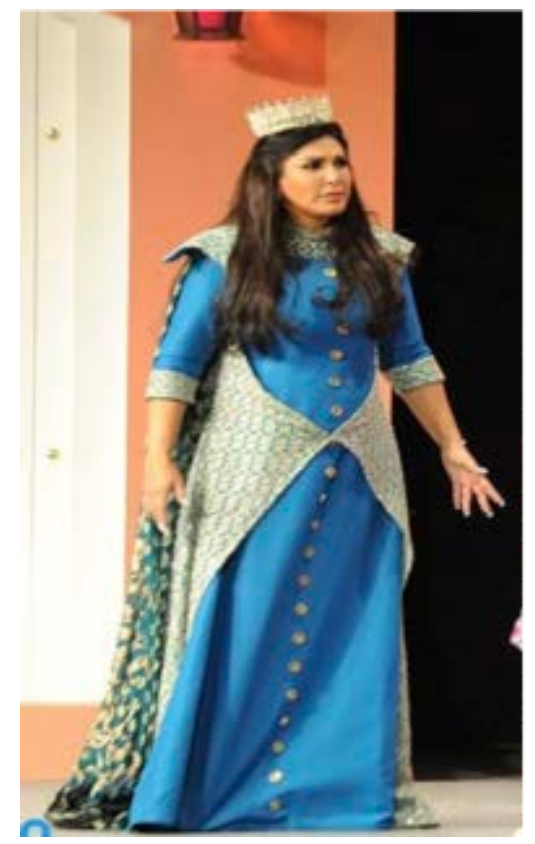

Figure 11. The final look of a new costume at the tailors. Nothing has been reused or recycled (textiles and costumes) from another play (source by author).

Play". According to (Evans, 2015) the author of the costume contraction book, comment "Costume contraction it in self an art form, technician create with limitation imposed by, budget, time and deign specification, the execution of that deign and the creativity and problem solving involved in its solution make works in the costume crafts a challenging and exciting creative and artistic endeavor".

\subsection{Summary}

Sadly when that found that there are was a much and tone of Kuwaiti traditions costumes are wasted and are not reused or recycle again for another production and they are wasted or through them away, specially the costume designer are not using any sustainable practice methods to reuse and recycling the costumes. The next play is fantasy (clowns play) will figure out how the third costume designer produce the costume to the final stage.

\section{Play 3: Showbiz}

\subsection{Background}

Showbiz it's the name of this play see Figure 12 and (for more details about the paly) see Table 3 . However, this play gathering different and verity of a (Clowns costumes) from different design and textiles, accessories in each costume for all the actress. However, each costume designer has he or she own philosophy of design a costume collection for any play show for the theater production (Clancy, 2014). And there is standard costume design process to design the costume. Which the most important things in designing a costume to drawing a sketch for the costumes to know how the costume will look on the stage and costume textiles 


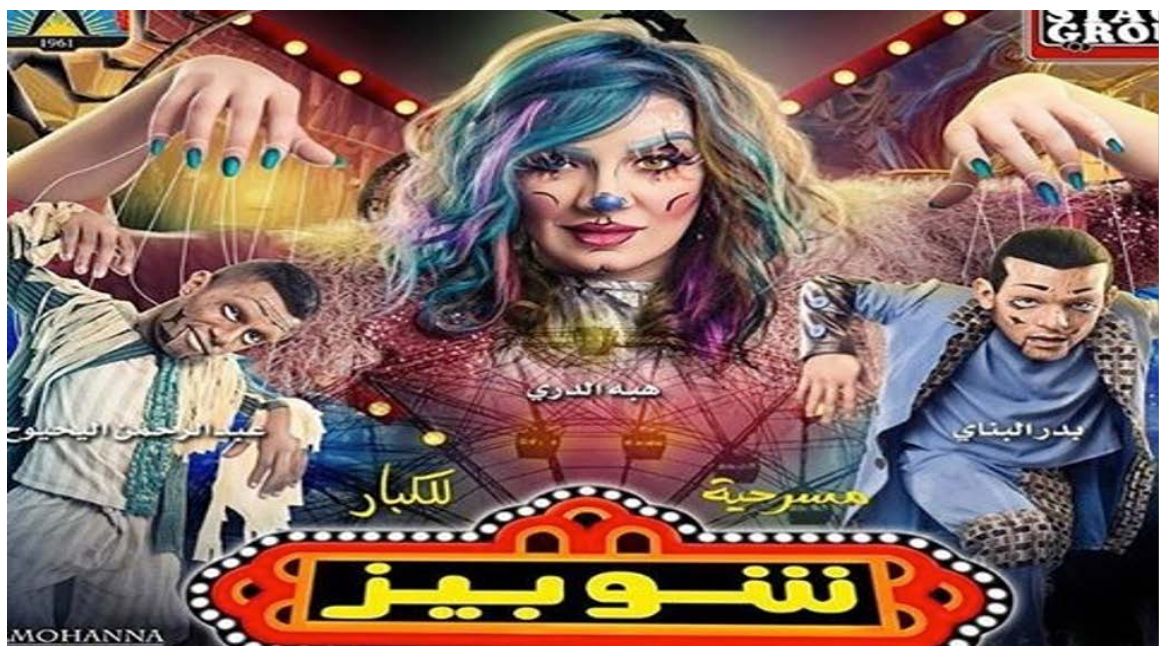

Figure 12. Showbiz Poster shows (source by author).

Table 3. Details of the play project.

\begin{tabular}{ccc}
\hline Site & Play name & Data Collector \\
\hline Tailor Studio & Showbiz & Author \\
\hline
\end{tabular}

palette that will use for each costume (Clancy, 2014). However, I will demonstrate the process of this costume designer (A.S) of designed and selecting the fabrics for this play.

\subsection{Lack of Understanding the Costume Process}

There is standard costume design process to design the costume. Which the most important things in designing a costume to drawing a sketch for the costumes to know how the costume will look on the stage and costume textiles palette that will use for each costume (Pollatsek \& Wilson, 2017). However while at the costume designer tailor studio, and from our informal conversation with costume designer there was asked her about the process of designing the costume for (Showbiz play) costume collection the costume designer (A.S) comment "firstly I examined the script, at that point I specifically went to the Kuwait materials advertise to purchase a textures and outfit extras for the ensemble, and the final prepare in my plan prepare are depicting for the tailor by a speedy draws (see Figure 13) of what I got to stiches sowing each outfit'.

Her process of designing the costume, specially the costume designer draw the sketches at the same time while the designer (A.S) at the tailor at the same day for the tailoring staff work, which lead to asked another question about if she deign any costume plot for the characters, preparing any costume textiles palette for all the (Showbiz play) costume collection, the costume designer (A.S) comment "No I did not I directly go to the textiles market and searching directly for the textiles fabrics, and in my head I have the design and then I draw a quick sketch for the tailor staff to sowing the costume collection". (According to American Association Community Theatre comment "It is the outfit designer's 

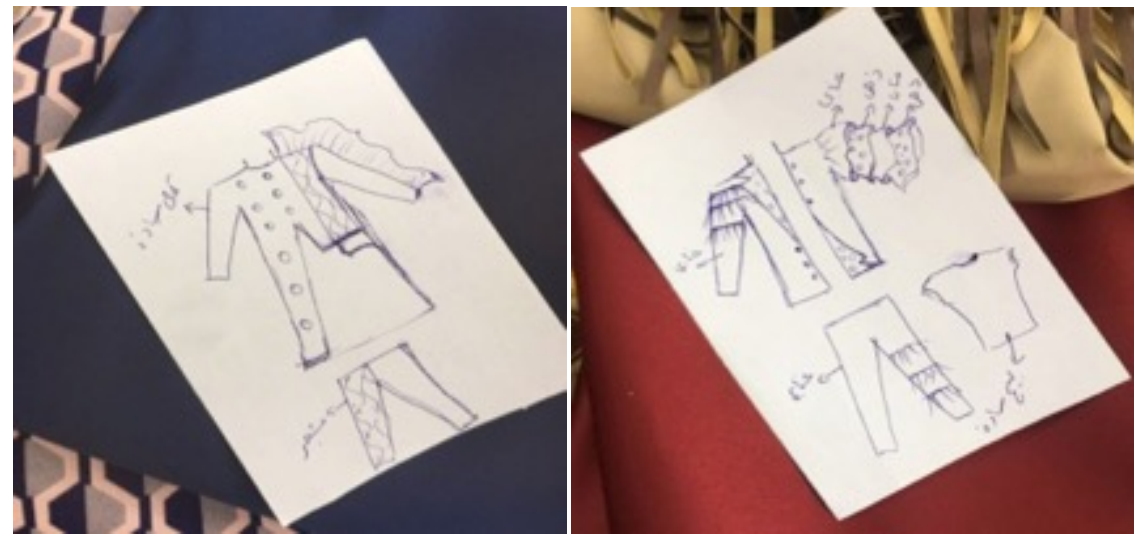

Figure 13. Showing the costume designer, hear quick deign while she is at the tailor to stich and sowing the costume collection for each character (source by author).

duty to draw up the outfit plot. The ensemble plot may be a list or chart that appears which characters show up in each scene, what they are wearing and their generally development all through the play". Be that as it may the outfit architect for the (Showbiz play) did not plan a clear outline explore for each ensemble or plan any ensemble plot, or outfit materials palette to know which kind textures will utilize for each ensemble, how the character will show up on the platform, the costume designer (A.S) works without any standard costume designer popular process to design the costume collection.

\subsection{Discarding Costumes and Materials}

Mostly all the costume designer in whole the world they are reused and recycling costume materials, or even they are looked firstly to the wardrobe costumes production companies, to looking and search of what they have of costume or textiles fabrics left from another play to use it, in a new play production. (Pollatsek \& Wilson, 2017) however while I am at the costume designer of the (Showbiz play), my eyes pay a attention about different and a variety of textiles, costumes and fabrics materials at in the studio from old plays the costume designer was designed (see Figure 14, Figure 15). And from our informal conversation about those tone fabrics and costumes, about the reason of not using any textiles or fabrics construction process or reused the or recycling or them for the (Showbiz play) at least as the costume accessories the costume designer (A.S) comment " $I$ always buy a new fabrics and textiles materials for any new play, why I will reused fabrics for a new play or used and old costumes, I want all my costume on the stage looking glamour's and new on the stage, and most the left costumes that I have theme from old play I do not used or reused them again, and mostly after a while I throw them away because they becoming old and dusty in my studio". However According to (Jones et al., 2013) "Certain constriction techniques allow the costumes to be more readily used in the future production, use the constriction ideas to make the theatres inventory of constructed costumes meet the goal of sustainable reuse". 


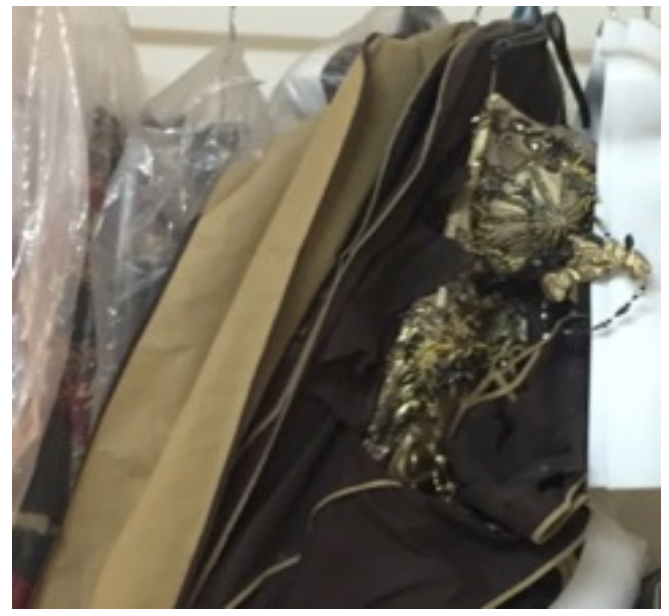

Figure 14. A verity of old dusty costumes from different old play are wasted and not using again for any costume projects in the theater (source by author).

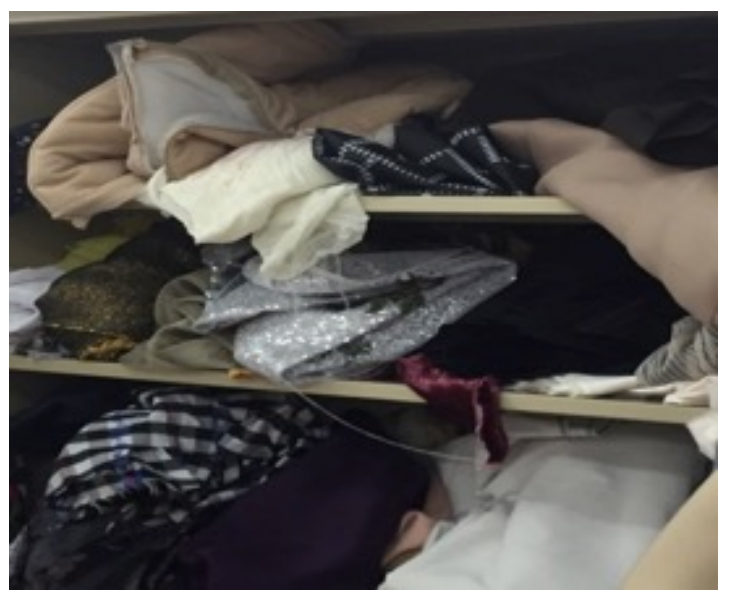

Figure 15. A tone of different costume textiles materials at the studio, are not reused and recycled again for any another play (source by author).

\subsection{Focus on Purchasing New Materials}

According to the costume designer for the (Showbiz play) "Al the costume collection for this play was cost around 2.400 Kuwaiti dinar, converting in pound currency around $6000 \mathrm{E}$, because every things are new and all the Kuwait textiles market are expensive, specially I bought a high quality of textile s fabrics for this play, to how the richness for each costumes for the character on the stage" (see Figure 16, Figure 17). However the costume designer her knowledge and vision about understating the costume process and sustainable process and practices, Are contrary to the conventional scientific theory according, to reducing the budget and reusing and recycling as much as you can of costumes and fabrics to presenting the costume garments in high creativity mind and costume designers skills and techniques of design any costume collection.

\subsection{Summary}

The costume designer for the (Showbiz play) had many opportunities to exploit 


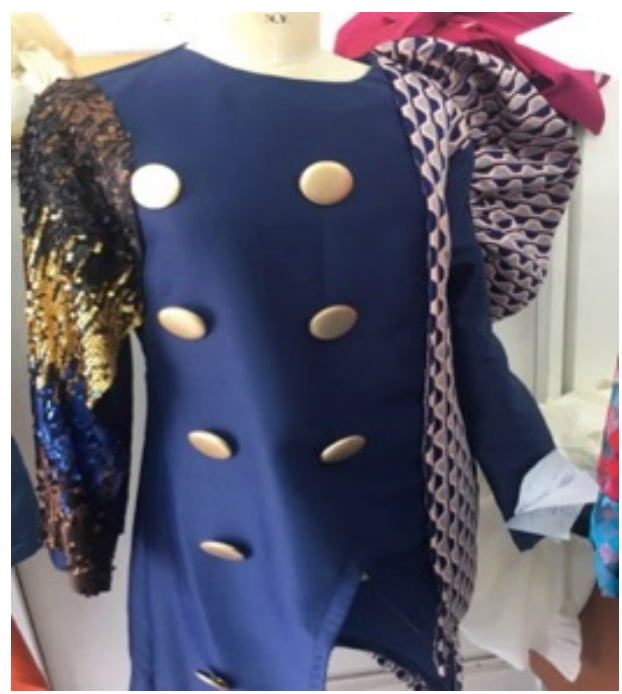

Figure 16. Rich fabrics used for make a jacket (source by author).

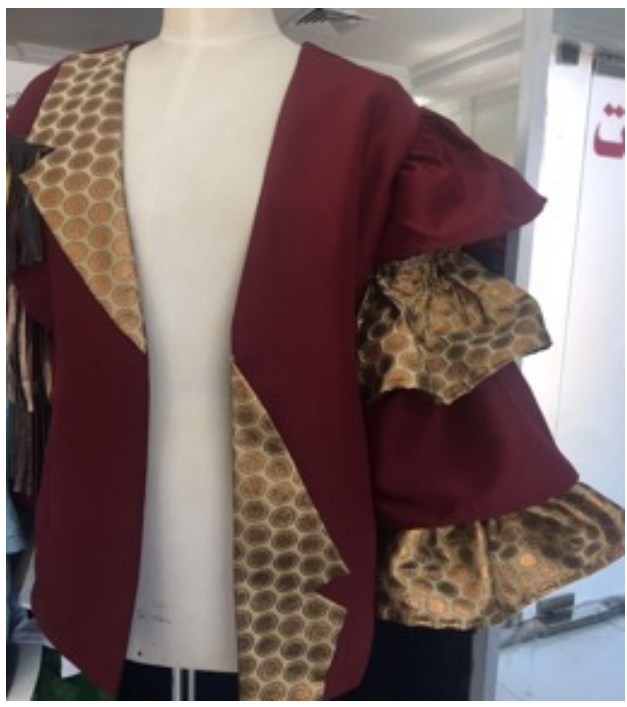

Figure 17. Expensive satin fabrics used to make the jacket (source by author).

in this play, according to reusing, recycling and using contraction techniques to creating a new costume all the old costumes she have in her (tailor studio) with al her tailor staff they was had a massive of opportunity, to carting a different costume collection for any play without purchase every time anew. The next play is fantasy child's play (Sally) will figure out how the costume designers produce the costume to the final stage.

\section{Play 4: SALLY}

\subsection{Background}

Sally is a comedy/drama child play produced in 2016 and the same this play was produced in Kuwait in 1992 (see Figure 18, Figure 19 and Table 4), those plays are gathering a variety of different costumes characters for the same play, scenario and costume characters, in this play (sally play) I will demonstrate the 


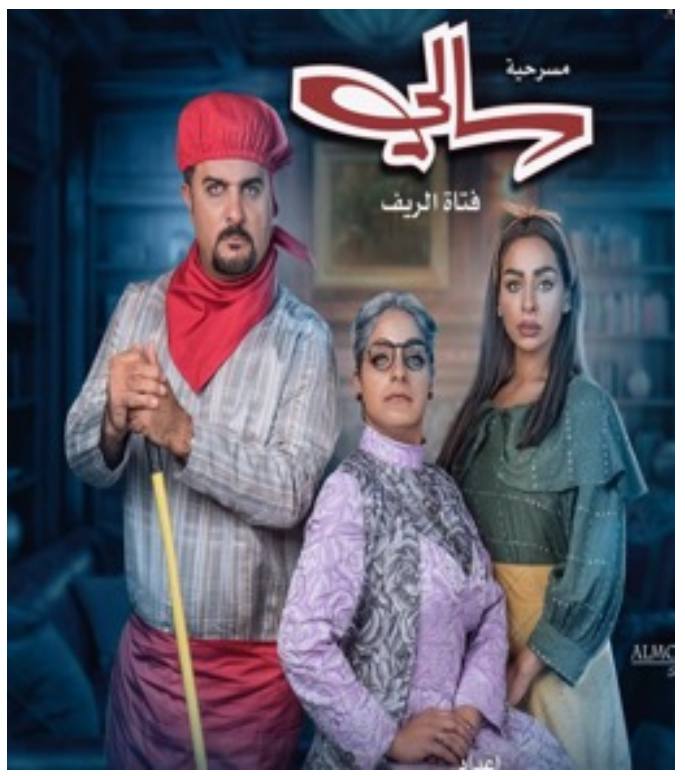

Figure 18. Sally Play Poster shows in 2016 (source by author).

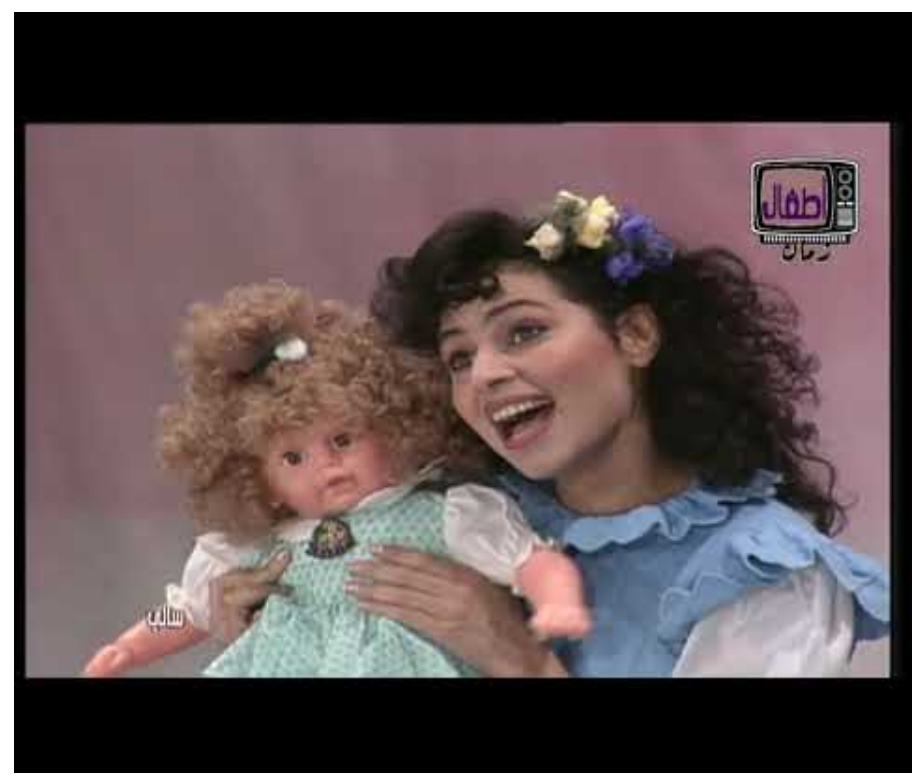

Figure 19. Sally Play Poster shows in 1992 (source by author).

Table 4. Details of the play project.

\begin{tabular}{ccc}
\hline Site & Play Name & Data Collector \\
\hline Tailor Studio & SALLY & Author \\
\hline
\end{tabular}

results of the processes of design the costumes, did the costume designer use any reuse \& recycle materials to designing the Costumes up to the final stage? Are the costume designer reuse and reuse the old costume from the original play in 1992 to reused or recycle them for this play in 2016? Which kind of costume material are used to design whole the costume character for the play? Are there is any sustainable practice method to designer the costumes? However, I will demon- 
strate the process of this costume designer of designed within selecting the fabrics/textiles for this play.

\subsection{Inadequate Understanding of the Process}

Reading the script of the play it's the first important step to, set up the characters list and to builds a string imagination for designing the costume (Clancy, 2014) however the costume designer for the (sally play) from our informal conversation about her process of deign the character costume for the sally play, (S.O) comment "as you know sally was child serious episodes (see Figure 20, Figure 21) when I in my childhood I have seen the carton episode for this play, so I have the imagination of the charter costumes of how they will look like, then I read the script to quickly, and I deigned all the costume according to my childhood imagination".

Her vision of understanding the process of design the costume leads me to ask her about the reason of did not drawing any sketches for the play to show the character and bring them alive on the paper sketches to know which kind of textiles materials are needed. The costume designer comment "I am not to proficient of drawing figures and ensemble, I am great of clarifying what I ought to the tailor and the staff their they continuously understanding how are each

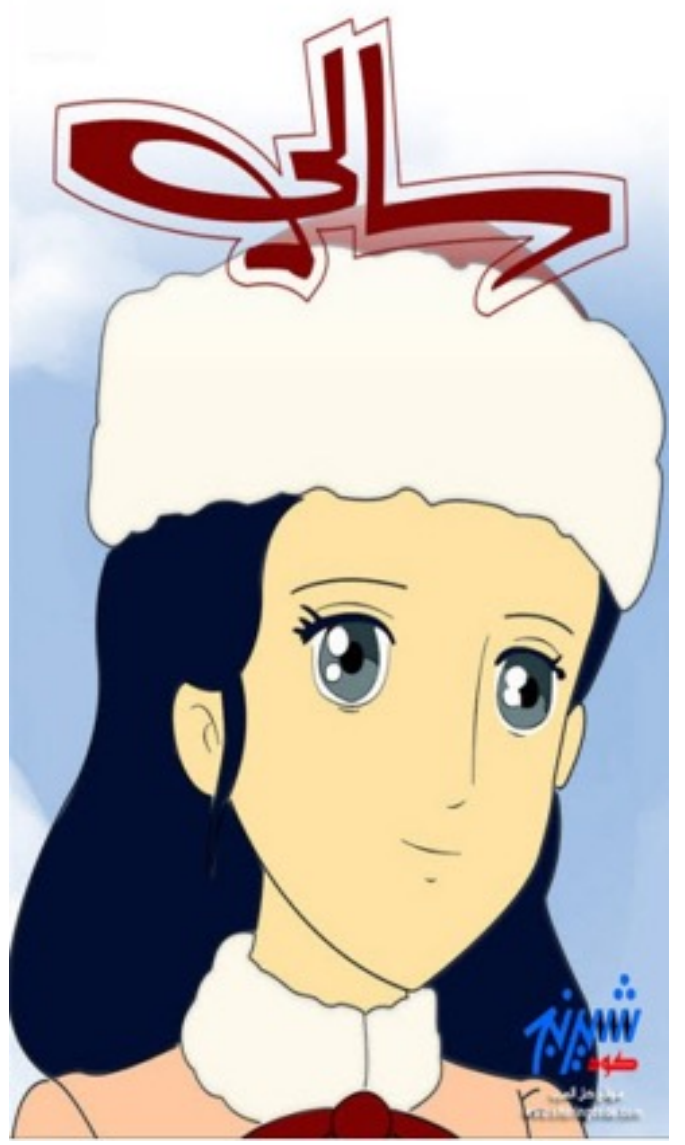

Figure 20. Poster of the Sally series carton (source by author). 


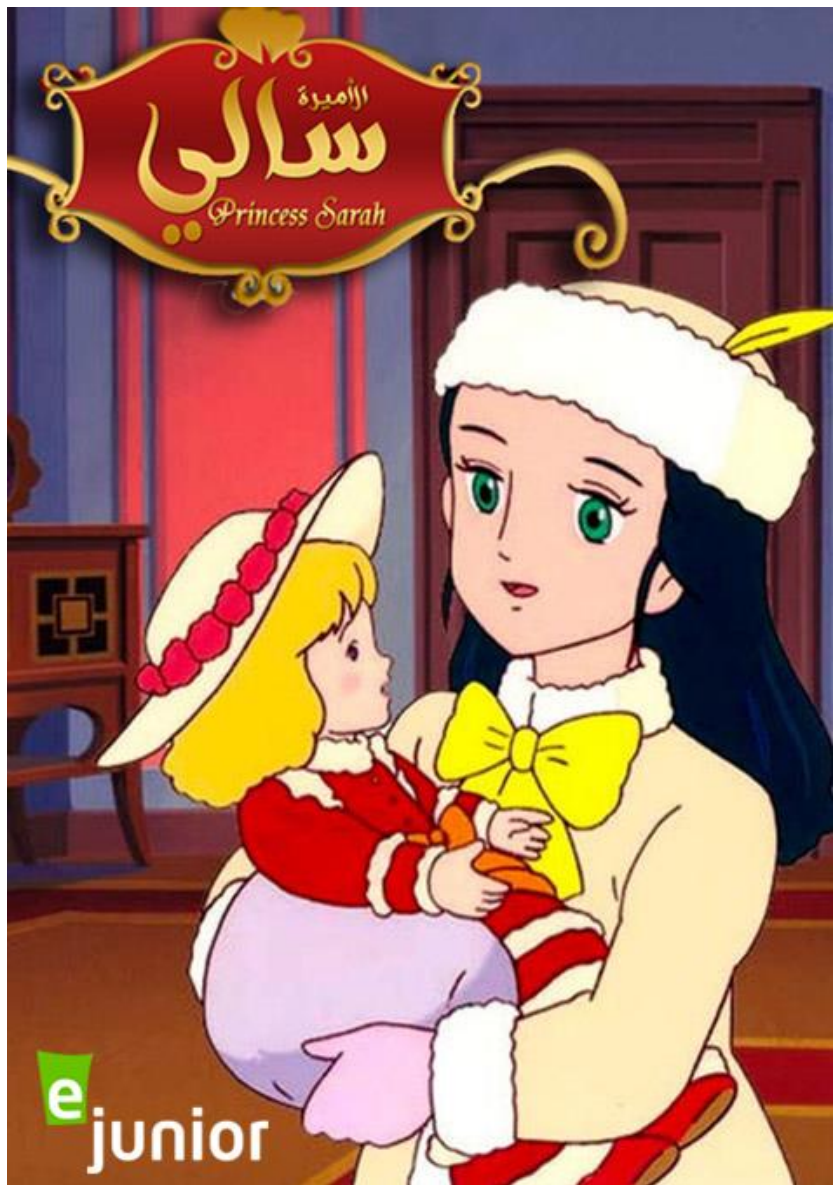

Figure 21. The costume designer use her inspiration and imagination to design the costumes for the play (source by author).

character will see like, and at some point amid my discussion with the tailor he draw a speedy draws whereas I am clarifying of what I require up to the ultimate see" (see Figure 22, Figure 23). This process contradicts the prevailing scientific theory in the field of costume design, which is should the costume, designer drawing the play character on the paper, to I identifying how the character will look like on the stage, to matching the textiles fabrics for each character, and to have a clear vision of the costume character for the costume.

\subsection{Discarding Costumes and Material}

As I comment the (Sally play) are originally produced in 1992, I was very exacting to know where are the costume for the original play was gone, why the costume designer did not reused or recycled any costume from the original play 1992, however the costume designer comment "To be onset I did not know, where are the original costume was gone, but, mostly all the costumes after finishes any play, the theatre production keeping in a few months and the new production show throwing them away, because the play is finish, and no need to use the costume again".

However, the costume designer for the sally play attempt to purchase all a new 


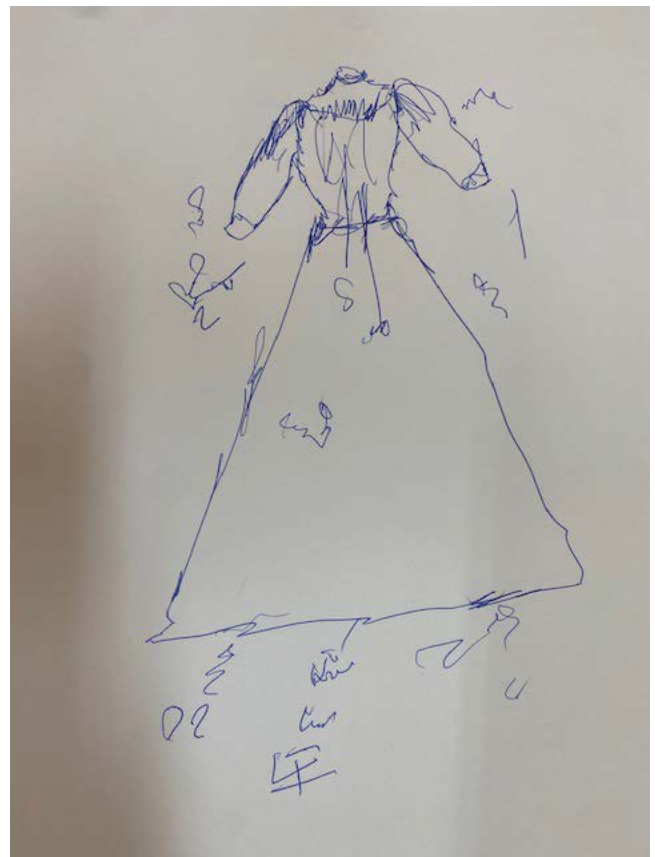

Figure 22. The tailor sketches, the costume designer vision of one of the characters, while she explains for him the character design (source by author).

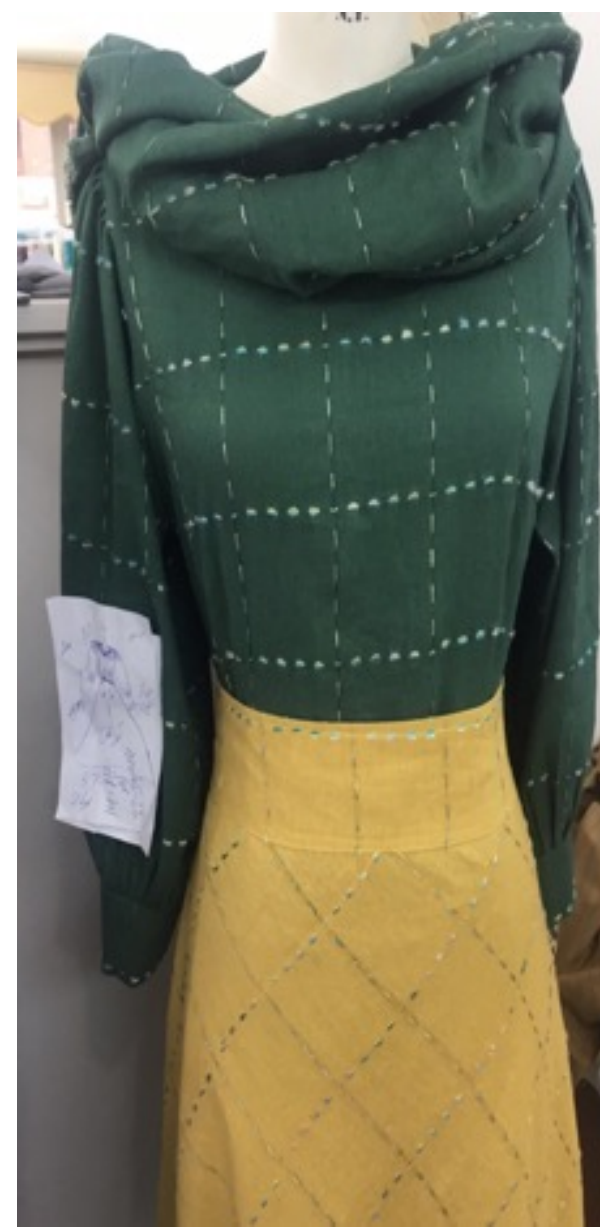

Figure 23. The final look for the character, sketches by the tailor. 
textiles fabrics and design all the costumes from the scratch. Figure 24 show one of the play costume character name (Sally) in 1992, and in Figure 25 the new variety of fabrics and textiles materials are deigned to up last stage of the costume, for the same character (Sally) in 2016. However, the costume designer they have a diversity of chooses to build and design the costume, into contracted costumes to allow to reusing the costume gain limit the number of new pieces or attempt to purchase a recycled fabric (Jones et al., 2013).

However All the (sally play) costumes character are new and nothings are reused or recycled, however the according to the costume designer of (sally play), that all the textiles fabrics materials for the (Sally play) costs around 400

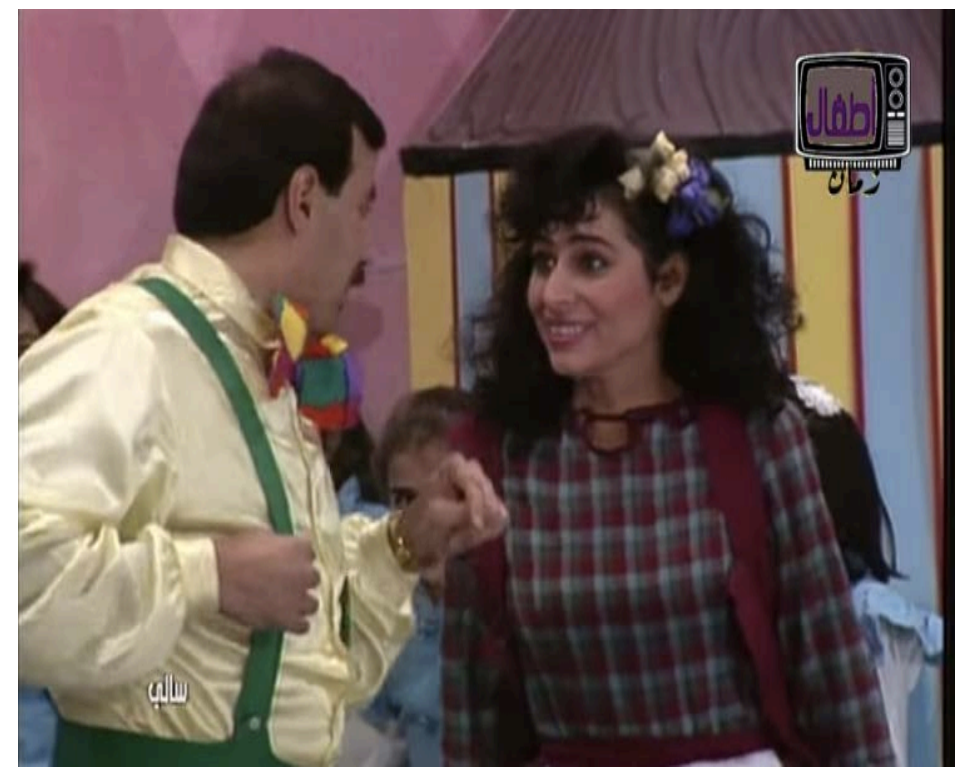

Figure 24. The original costumes for the character (Sally) in 1992 (source by author).

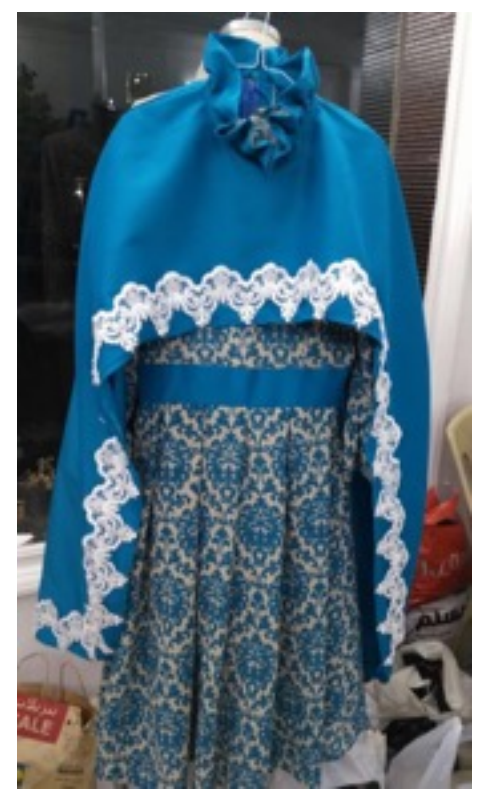

Figure 25. The final look for the character, sewing by the tailor (source by author). 
Kuwaiti dinar, in UK currency around $980 £$ (see Figure 26), additional cost for the tailor staff to finishing all the costume around $1250 \mathrm{E}$, the total costume for the full (Sally play costumes) cost around 2230E (see Figures 27-30) down below. Hens was asked the costume designer for the sally play, about the reason of not using the reuse and recycle textiles or garment for the play, the costume designer comment "I have never used this method before. I did not practices the recycling techniques of the way of constructed the piece of garments, recycle them again to produce them for another show, I thinks this is to professional technique, I did not stayed it before in any costumes classes in Kuwait, and it's hard for my skills at the same time".
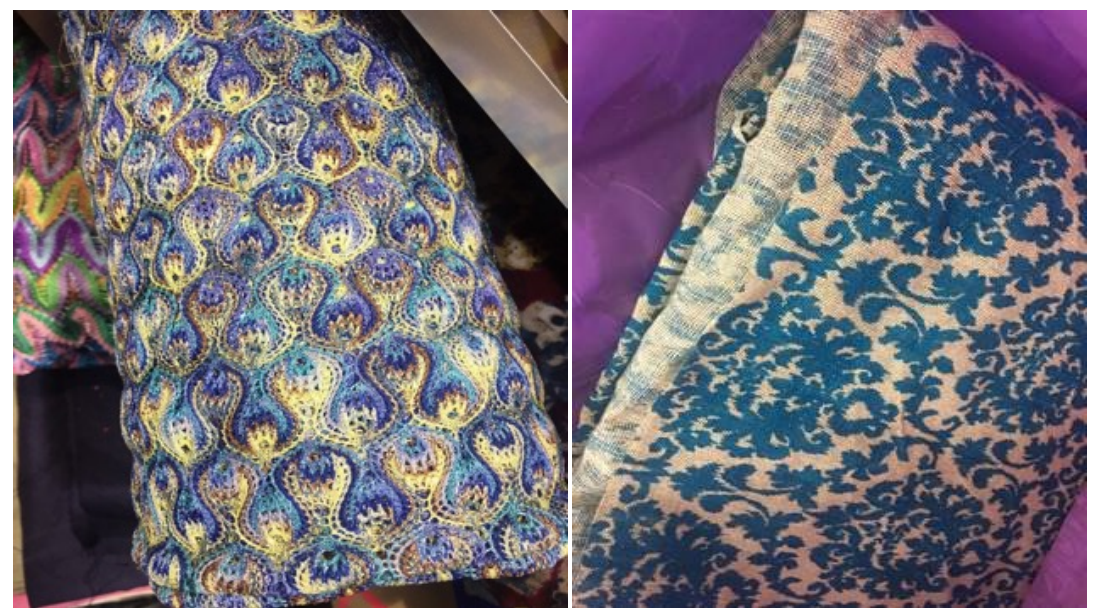

Figure 26. The new textiles fabrics for the (Sally play) costumes characters (source by author).

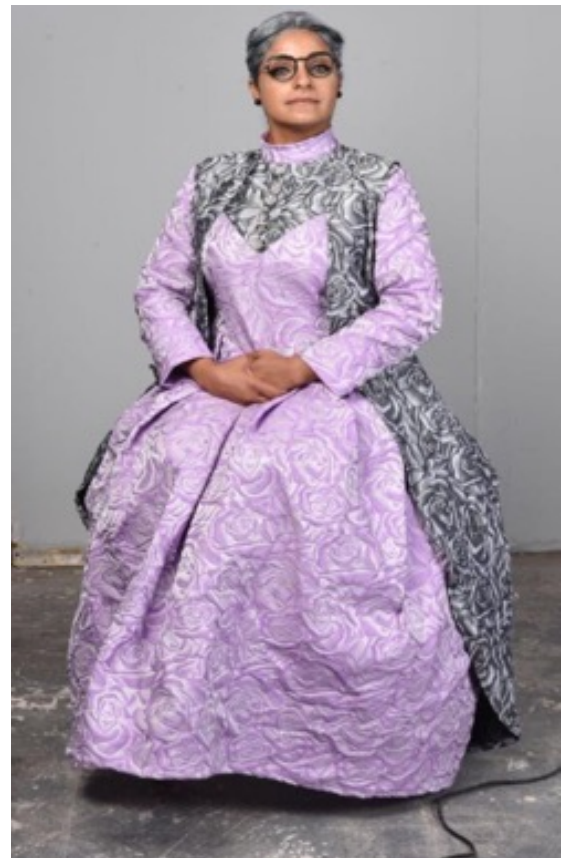

Figure 27. One of the characters in the (sally paly) wearing totally anew costume with an expensive unrecycled or reused fabrics (source by author). 


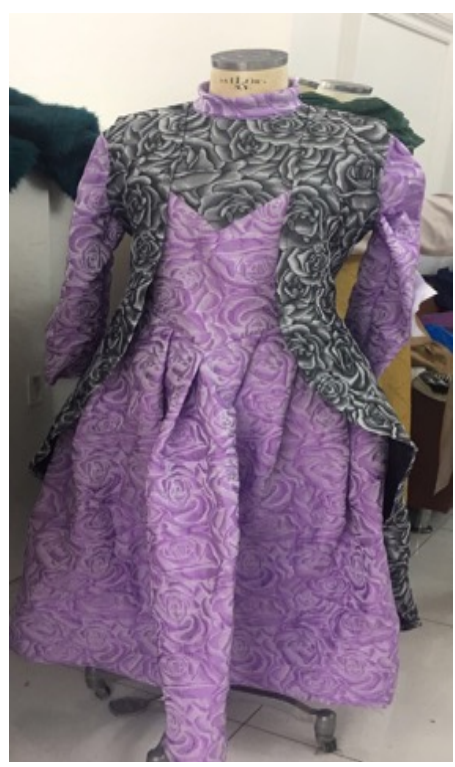

Figure 28. The same costume while under the process of sowing \& fitting at the tailor store (source by author).

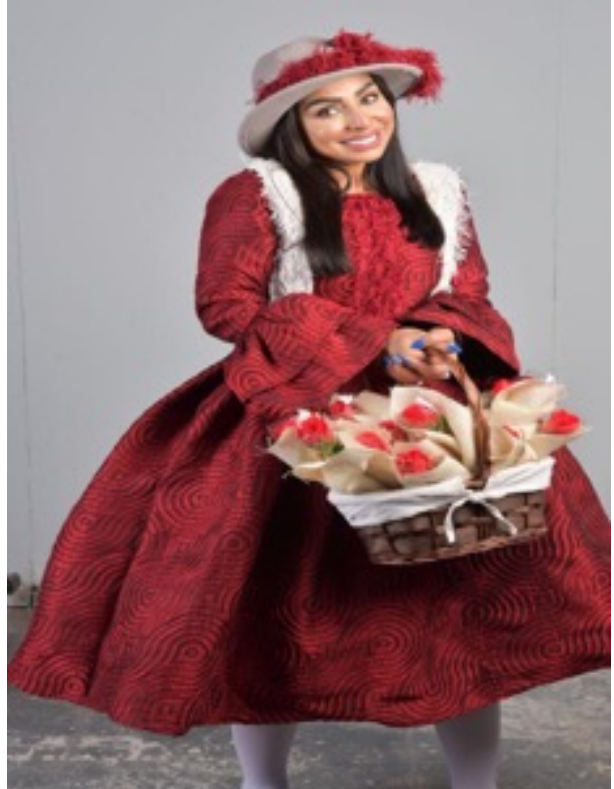

Figure 29. A character from the play wearing the final up stage of the costume (source by author).

\subsection{Summary}

However, the costume designer he/ she duty are to solves problems collaboratively to make a sculpture of fabrics that fulfills the visions of the sketches and comes to life on the stage. The costume designer for the (sally Play) gave a huge evidence of the low and lack of understand the sustainable practical skills, of reusing and recycling the costumes for the another show, or to find another solution to gathering and matching the fabrics in sustainable way such as recycling the fabrics and sowing and matching them for one of the characters. 


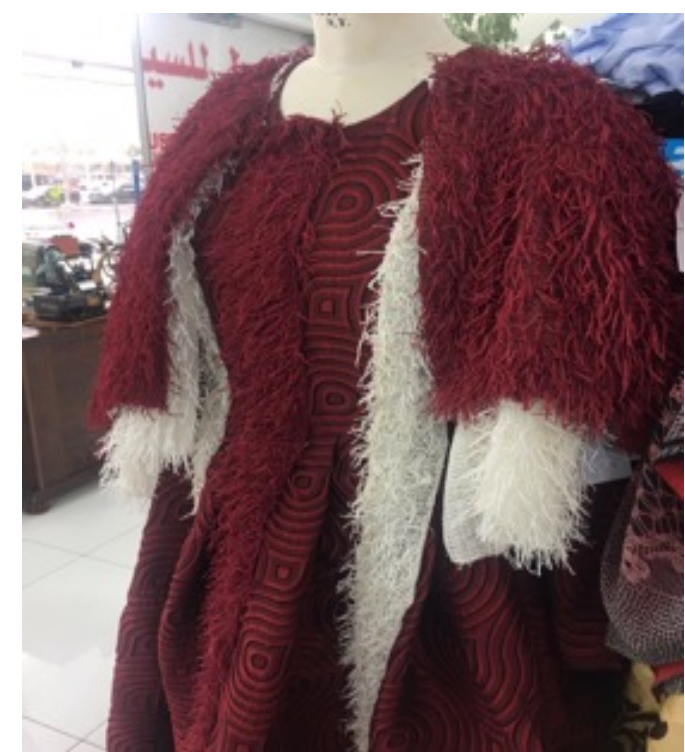

Figure 30. The same costume while under the process of sowing \& fitting at the tailor store (source by author).

However in phase 1 the (Case study 1 Kuwaiti costume designer play costume productions), demonstrated 4 Kuwaiti costume designer, showing their process of the way of producing costume on the stage, which kind of practical skills they have, their knowledge about the way of reusing and recycling costumes, textiles fabrics, the reason of un using any practical sustainable practice on their design, which is one of the main research objective is "To explore the current design process and the productions used by costume designers in Kuwait". The following segment I will display four UK costumiers interview, I observed their way of producing the costume on the stage.

\section{A practical process of making costume by UK costume designers.}

\section{Introduction}

In this section I will introduce the process of design and producing costumes by the UK costume designers in different plays (show) the way of selecting costume materials from different cities in the UK, I will figure about are there any sustainable practical process on their design, are their using any reuse/recycle costumes or fabrics, up to the final stage for the costume, are they always purchase all the textiles fabrics from the textiles fabrics, or they have a different solution to deigning any costume character for any play, by using a sustainable practice method of reusing and recycling costumes and fabrics. In the next section I will introduce the UK costume designers' practices.

\section{Play 1: Protein; May Contain Food}

\subsection{Background}

(Y.N) is The costume designer for the play (Protein: MAY CONTAIN FOOD) (see Table 5) he is a theatre costume designer worked in Theatre Design at the 
renowned Motley Theatre of Design in London, the (MAY CONTAIN FOOD), this play are a witty piece of move and music theatre is propelled by social events and life at mealtimes. The entertainers welcome you to sit at a table, offer a tasting menu and after that serve you and appear that investigates our relationship with nourishment (see Figure 31) (Anon, 2016). In this section will demonstrate the process of the costume designer design and crating the costumes, how he designs the costume, selection the fabrics and textiles materials especially for this play (MAY CONTAIN FOOD).

The costume designer (Y.N) providing a huge evidence and example of his a variety of experiences related to the subject area (Reusing and recycling the costume and materials in the theater at this play (Protein) see Figure 32, however

Table 5. Details of the play project.

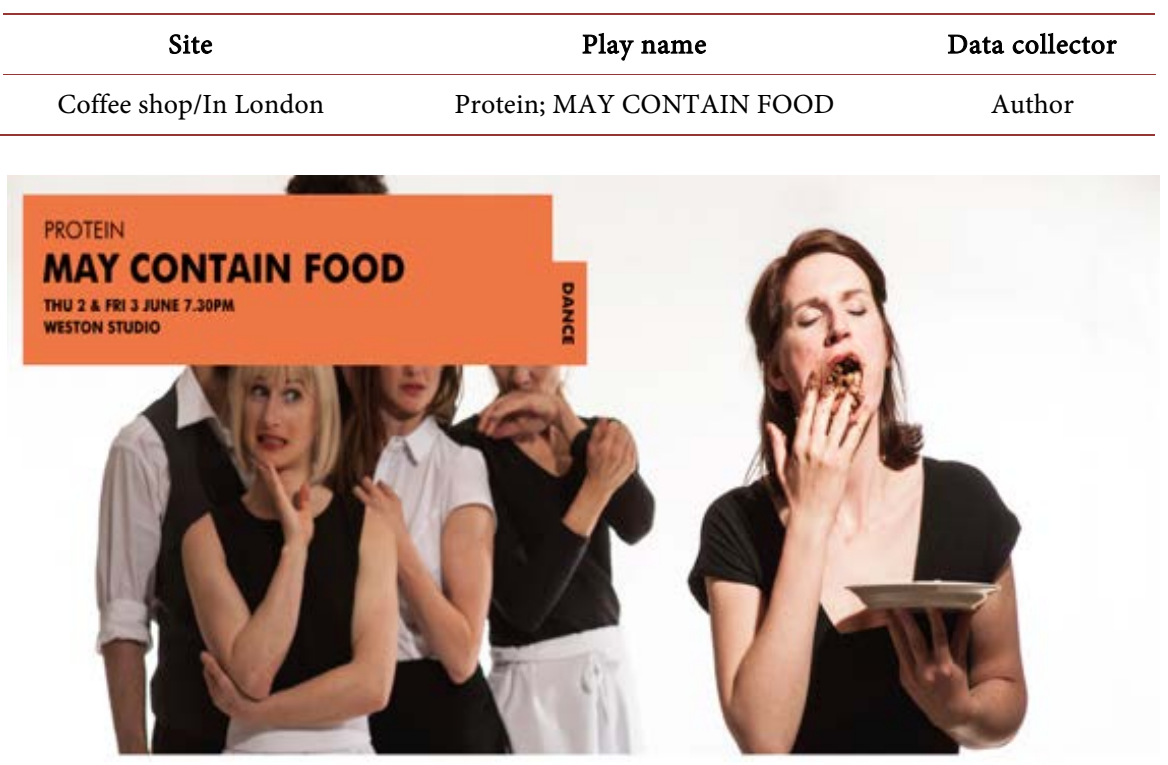

Figure 31. The poster for the play (Protein: May contain food) (Anon, 2016).

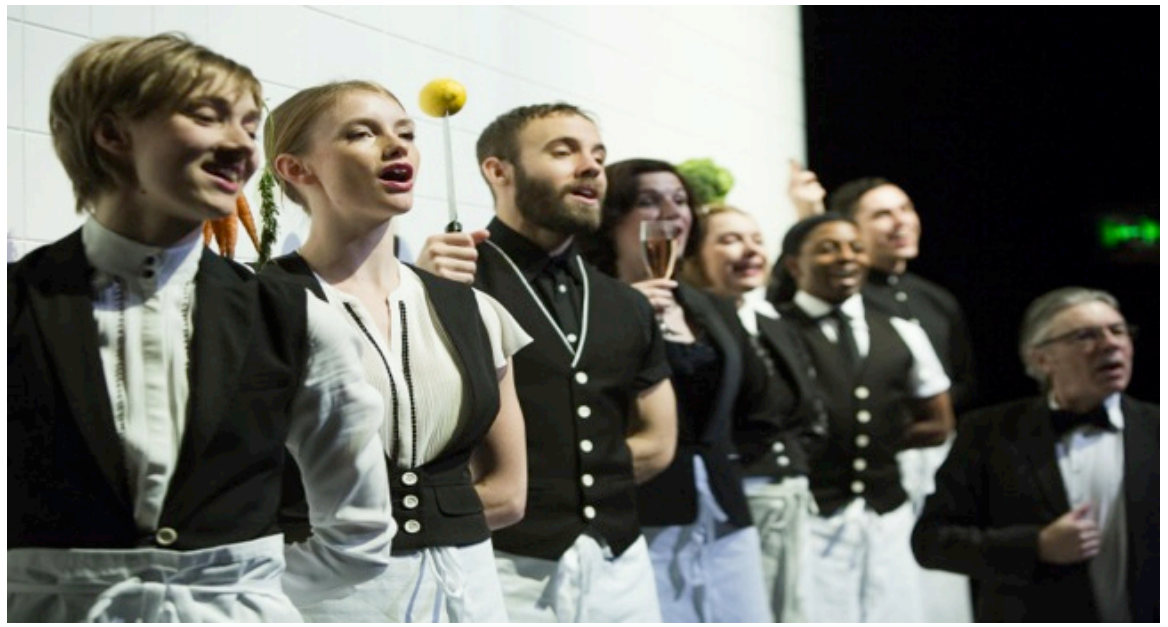

Figure 32. The costumes and textiles materials that are used for the play (protein) at the UK (Anon, 2016). 
(Y.N) comment about his general process for designing the costume and for producing and crating the costumes for a (Protein play) explained by:

"Perusing a script, at that point I talk to the executive. At that point the primary thing you are doing is built up the, inquire about is crucial within the creation of costume. Then after merely go through your drawings. I think a drawing is additionally an awfully great way to put together how this character will combine, how this last see will be and continuously from the $2 \mathrm{D}$, for the $3 \mathrm{D}$, continuously there's an enormous travel, which varies. Drawing and third, whenever you're going to the manufacturing shall we say, if you're going to find the textiles and to hiring some costumes from some companies at the UK such as (hire companies like at the National Theater, The Academy, Angel)". The costume designer (Y.N) give a fully argument of the process of design and creation the costume, did not mention to go first at the textiles market he suggest going to the hiring which they hiring it's part of reusing the costumes from previous play to another play. Mostly all the UK and western costume designers their process of carting costume are looking first to the costume storage, to reused or recycling costume (Monks, 2010; Jones et al., 2013).

\subsection{Reused and Recycled Costume from the Wardrobe}

However during the conversation with (Y.N) regards of this question, are you reused and recycling the costume for this play (Protein) or for any production (Y.N) stated:

"Yes, absolutely I reuse and recycling costume, because sometimes in the production their budget is ridiculous specifically for this play the budget are too low. And sometimes you do not have the money for the many productions like that. Just like example, I went to the storage (wardrobe) at the company. I spent two days going inside of bags and I've found some amazing stuff from the past productions of the company, which I literally just re-dyed, or customize, change the bottom, or adds a little detail to it. Suddenly, those garments became a completely different at the (Protein play) on the stage, it's was an amazing play with a reused and recycling costume" (see Figure 33, Figure 34).

However the costume designer (Y.N) also explained that costumes for the play are mostly are shows that it's a normal attitude process between the costume designers, (Y.N) noted that he was worked in many different period play are run for week, and his process of design the costume and selecting the materials (textiles) for period play comment:

"If it's a period costume and the play is just run for a week, there's no really need to sometimes for you to manufacture it. Which basically answers your question how much you use things. You go to a hire company. You hire a piece, which you really think, 'Oh, that jackets is great, but maybe I make these trousers but I keep those jackets.' Yes, it's something, which you pay for 


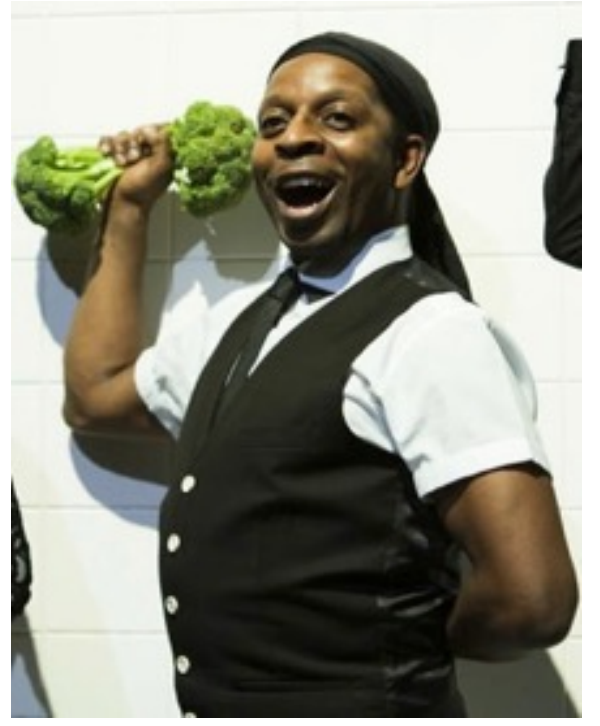

Figure 33. Reused vest jacket from the costume storage (Anon, 2016).

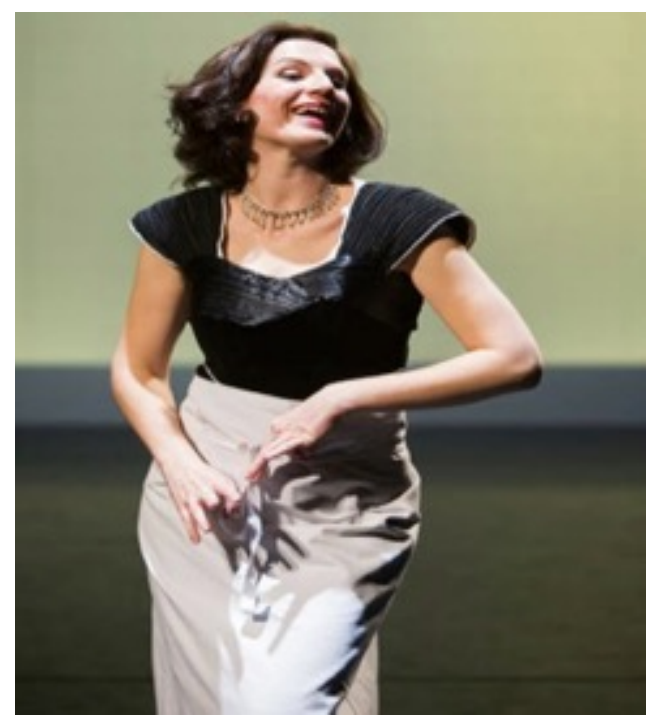

Figure 34. One of the main characters wearing a recycled dress and a reused left fabric (Anon, 2016).

a week period. Then you turn back to another production. That jacket might be in many shows."

The costume designer (Y.N) his process of designing and selecting the costume materials give the garment of the Reused assemble bulky stocks of costumes (garments) from during several years of dressing costumes in theatre productions, It's been a useful solution to build and construction the pervious costumes to other play productions, by adding newly acquired (textiles, garments) to the existing garments, putting two of reused costumes from the costume wardrobe together and make them fit to the characters on the stage. This sustainable designing and making costumes it has helped to give the costumes another longer life, as costume designer working in this way of the designers process, it's easy to shape 
costumes which assembled many of the costumes and producing one costume for the characters to perform on the stage.

\subsection{Summary}

From the play (Protein; MAY CONTAIN FOOD) show the designer process and techniques of reused and recycling the costume in the theater, delivered a successful play in the stage, as it's from his costumes work that there are the opportunities and creative sustainable methods regards of reusing the costume and turned the (recycling them) to another costume character. The next play is drama play by William Shakespeare.

\section{Play 2: CYMBELINE}

\subsection{Background}

Cymbeline play see Table 6, too known as Cymbeline, Ruler of Britain, may be a play by William Shakespeare (see Figure 35) set in Antiquated Britain and based on legends that shaped portion of the Matter of Britain concerning the early Celtic British Lord Cymbeline. However the costume designer for the play (CYMBELINE) (B.G) is a maker of professional high quality costumes for theatre, have extensive twenty years' experience of cutting and making period costumes, from her experience will demonstrated her process of design crating the costume, which kind of methods are used to producing the costumes for the Cymbeline play) and in general of her design processing works.

\subsection{Successful Process of Making Sustainable Costume}

The consummately costume maker (B.G) has an excellent of using the sustainable

Table 6. Details of the play project.

\begin{tabular}{ccc}
\hline Site & Play name & Data collector \\
\hline Yorkshire art space exchange place studios Sheffield & CYMBELINE & Author
\end{tabular}

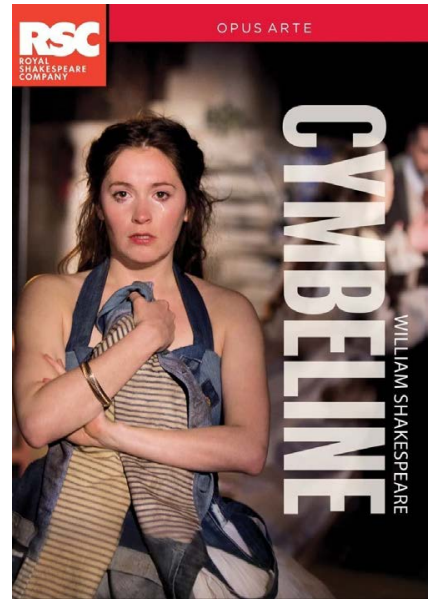

Figure 35. The poster for the play (CYMBELINE). 
costume strategies method such as cut and constriction skills, (Reus, recycling and up cycling) combined with an ability to interpret deign, (B.G) described her general process of making and deign the costume in her costume maker journey and for the play (CYMBELINE):

"My general process of deign or making costume as I am a costume maker, I guess, mostly. Often, I do things that are from real historical references. Looking through the references. Sketching, then start to work on the pattern. I'll draft the pattern. I'm doing from the measurements, however I've got enough actual fabric to (reused textiles) make things longer if I need to Then, after the fitting mostly all the decisions then are pretty much made. Then, I'm altering. Cutting anything else that I ought to. Linings, whatever. Then, going for finishing it."

However during our conversation ate her Studio in Sheffield, I was very passionate to know more about her process of (reusing or recycling the costume) as a costume maker, cutter and a professional costume alternation, how (B.G) applying those methods for the costumes in general and for the (CYMBELINE Play) she stated:

"Well in general, sometimes it'll go in the store (costume wardrobe) to explore some reused costumes and textiles materials that might be reused looking for a well-(worn jackets).It might get broken down a bit more, or it might get up cycled in terms of using that, as I worked to up cycled whole the costume for the (Cymbeline play)" (B.G) (see Figure 36, Figure 37).

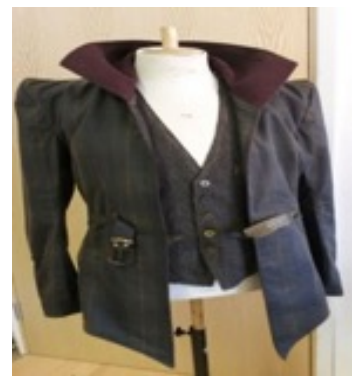

Figure 36. One of the reused Jacket are upcycled (source by author).

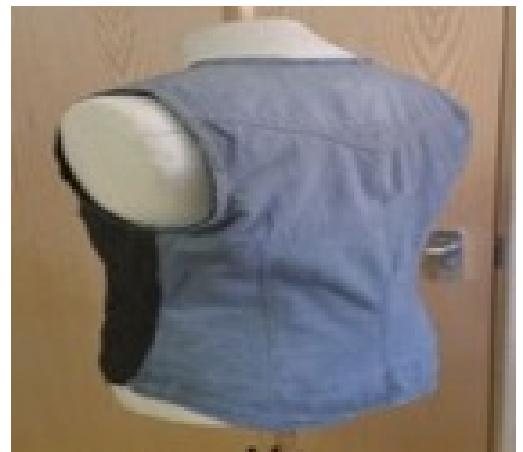

Figure 37. Working on used jacket, cutting the sleeve and transfer it to waistcoat (source by author). 


\subsection{Upcycled Textiles (Fabrics) Materials}

Uncycling can be considered as an example of recycling (Garments) costumes and materials is a way of processing an item to make it better than the original, (Muthu, 2018) crating something's new from old reused or disposed materials (textiles, garments) taking something that doesn't fit or is stained/torn and reuse/recycle it for a wearable product from it. In addition the benefit if the upcycling are It is a way for and designers to be more sustain with leftover materials such (textiles, clothes) to give new life to worn-out (Payne, 2011) however this and introduction to the way of the (B.G) costume maker are used for the (CYMBELINE Play) the costume described her upcycling sustained costume and materials for the play project she Comment:

"I did this project last year costumes for Cymbeline at the RSC, with the collaborate designers (A.F), the play was set in a kind of nonspecific period. There were a lot of raw edges and using pocket flaps as collars and mixing it all up in that way. We up cycled all the costumes. They were all patched up together; they might be denim with tweet, with stitching over the top (see Figure 38). I had to make one jacket for new. It was mixing different fabrics together. I started with the denim jacket, and I had to add some left used fabrics that I had from many previous play projects at my studio, added it to the jacket it and make the sleeves longer (B.G)."

Her strong argument followed by another way of vision of reusing and recycled textiles and fabrics from our conversation comment about the way that

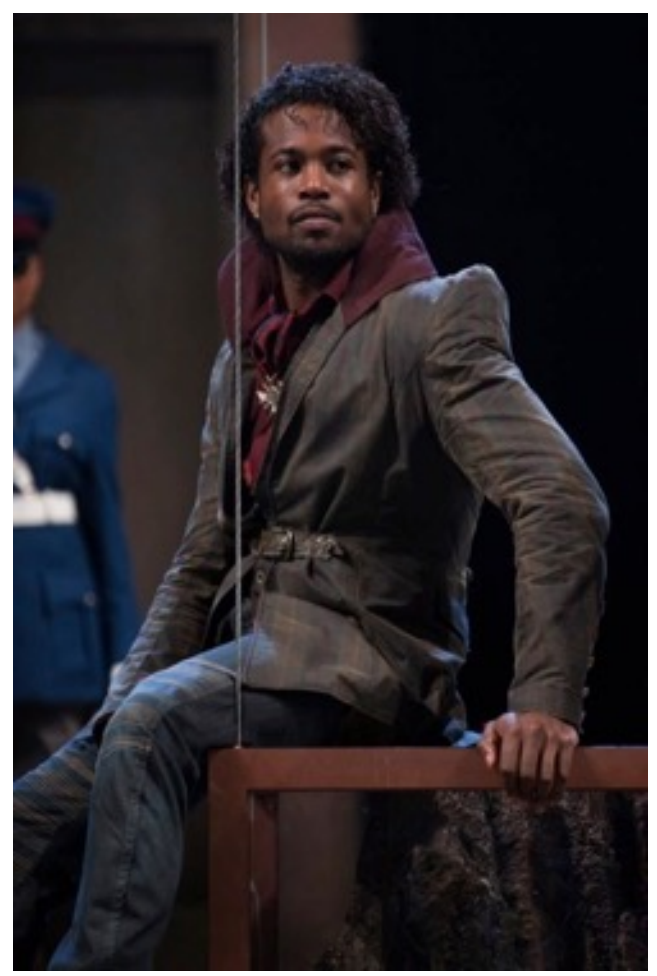

Figure 38. A recycled jacket with mixing of different reused fabrics (source by author). 


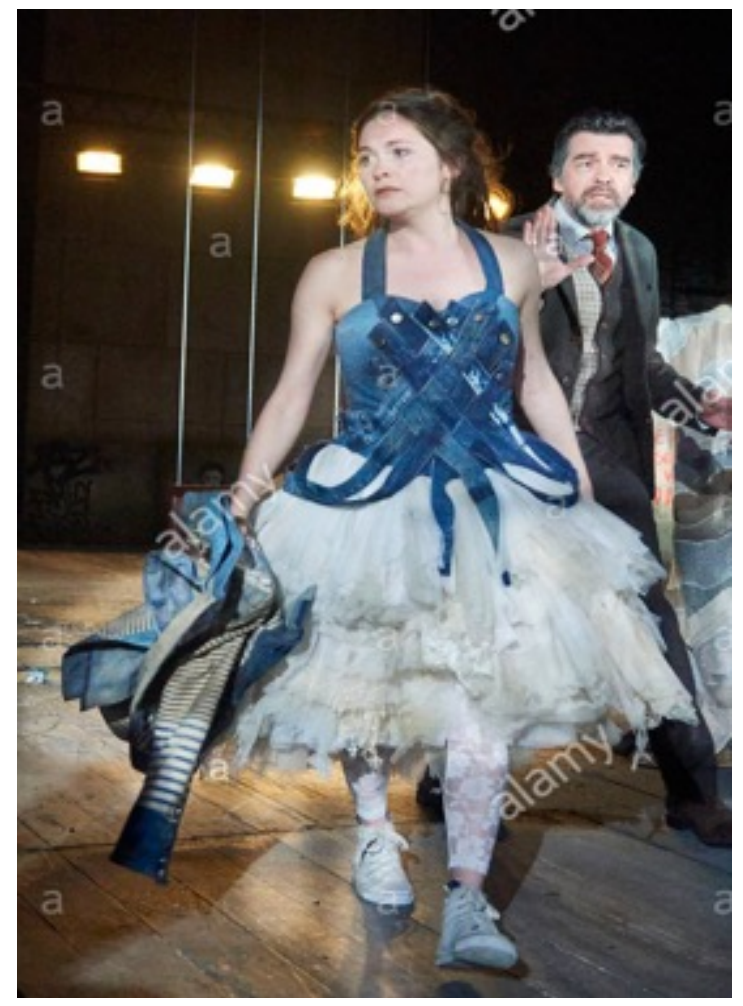

Figure 39. Recycle skirt used a variety of reused left fabrics (source by author).

she used some of left fabrics and textiles in hear studio, and Added and stuffing them for the one of the (CYMBELINE) character that character skirt need a much of skirt with old Fabric's some sort of skirt bite to it to make it look, dirty like old and dirty skirt (see Figure 39).

In addition (B.G) comment about the long life for the fabrics and clothing (costume) to reused and how this method is saving the time and budget for any play project she stated:

"I keep amounts of fabric that are neat or over, then if somebody needs a waistcoat, or a lining, or even possibly a pair of trousers or something like that you can get that out of what you already got. Sometimes all these bits of fabric that were saved can come together in one to save the day for that scene. That saved a lot of the budget that time (B.G)."

\subsection{Summary}

The costume maker for the play Cymbeline had given a huge evidence regards one of the researches aim to extrapolate from the aforementioned working guidelines policies that could promote reduction of textile consumption, making production more efficient and diminishing textile waste in Kuwaiti theatres. (B.G) Thus, piece of clothing creators is well-placed to arrange for the impacts of their articles of clothing within the plan organize. For a design article of clothing, the lifecycle starts at fiber (support), sometime recently moving through to material generation, piece of clothing design handle, fabricate, dispersion, retail, 
utilize stage, and inevitable transfer (grave) (Fletcher, 2008; Muthu, 2018). Her sustainable practices of process of design and creating the costume, with using the different of sustainable methods (reuse and up cycling) are an evidence that there are huge possibilities for the costume designers in Kuwait to reduce the costume and textiles waste and applying the reuse and recycling strategies in their design and making costume process. The next play is fantasy circus performers' plays.

\section{Play 3: Circus Performers}

\subsection{Background}

Circus Performers is (S.F) costume designer fields work, she is an international with over 10 years experience, crates captivating performances combing daring feats with elegant shape to give mesmerizing effect, during our interview she explained for me hear sustainable practice work during hear design process and provided me with some a visual images from past works (see Figure 40) and Table 7, explained every single costume how she worked on it, what are the process of designing and producing the costume? Which kind of materials are used, especially hear fields works are interesting working as costume designer in a Circus.

Each costume designer he/she have a different and a variety process of deign the costume before crating the costume, which this process are the important begin process, because it's show the costume designer the last clearness vision about how the costume will look like on the stage (Jones et al., 2013), which kind of materials will use to sowing the fabrics, or if there are any left textiles fabrics from old play can reuse are a costume can recycled (Fletcher, 2008), in this way

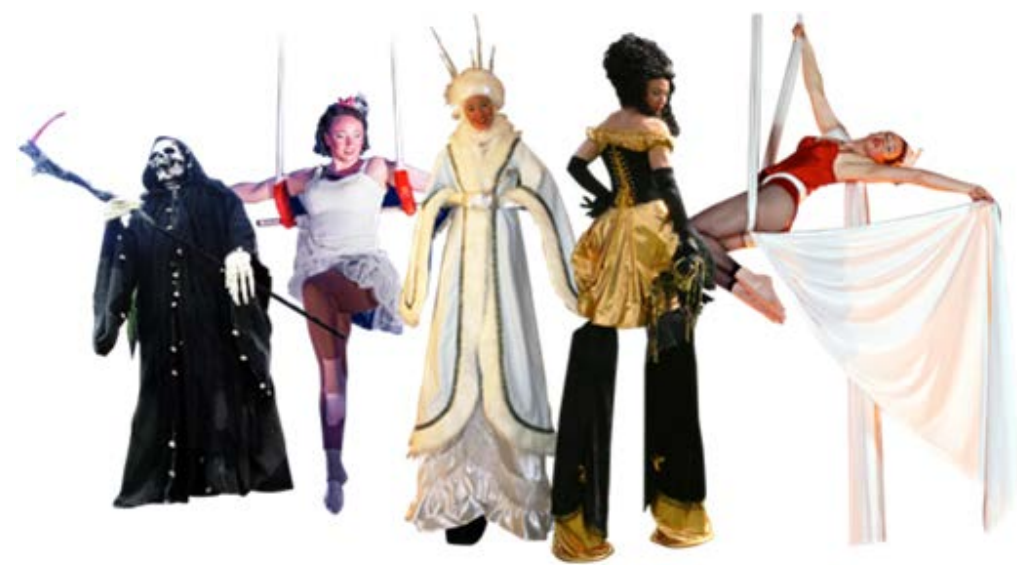

Figure 40. A mix of a Varity reused and recycling costumes in the Circus (source by author).

Table 7. Details of the play project.

\begin{tabular}{ccc}
\hline Site & Projects Name & Data Collector \\
\hline Coffee shop in Sheffield & Circus performers & Author
\end{tabular}


appearing the reality of feasible hones being natural, financial, and inventive boons, as different researchers on economic plan have more than once pointed out (Morgan, 2009; Jones et al., 2013). However, the costume designer (S.F) explained hear variety of process design and making the costume for the circus performances stated:

"I make costumes for usually, circus performances because that's my discipline I use (Pinterest) (see Figure 41) quite a lot because I use that to gather ideas together and put them all in little mood boards online that I can look up on my phone,. Then I will decide what fabrics will use because there's no limit to your imagination, but there is limit to what fabric and needles can do for the costumes (S.F)."

In addition, the costume (S.F) designer comment about her process and ideas of selecting the fabrics resources and for the Circus Performers stated:

"It usually follows a process if you get some ideas together, you find the fabrics that you want to reuse, Have a look at my fabrics at my tiny store. Then there's always kind of an exploratory phase of making practices, and mockups fabrics, and playing the fabrics, seeing what you can do, whether you can glue things to it, that kind of stuff (S.F).”

\subsection{Sustainable Recycling Materials Mermaid Costume}

Throw the discussion with a costume designer (S.F) around her costumes project during hear work at the Circus, she provide for me of hear past work project was used variety of different costume design technique and practices for each costume she was made the Mermaid costume (see Figure 42) (S.F) comment about this costume said:

"I made a mermaid costume last year, it's totally recycled costume (see Figure 42 ), the bra which top is built on reused and shells were saved from a nice

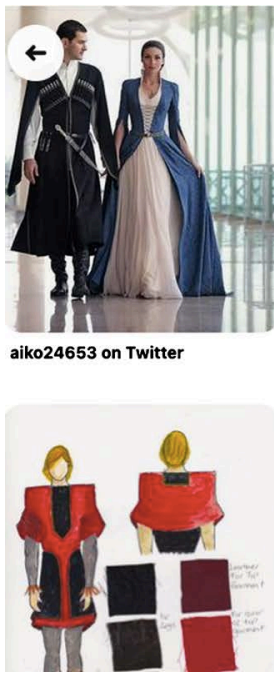

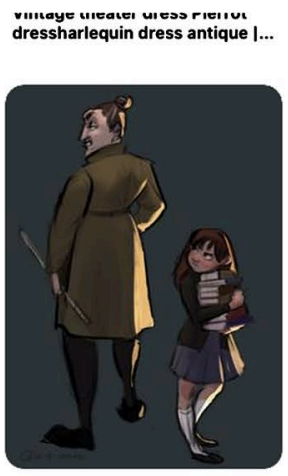

Drawing Past My Bedtime

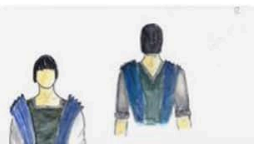

Costume design sketches for Romeo \& Juliet

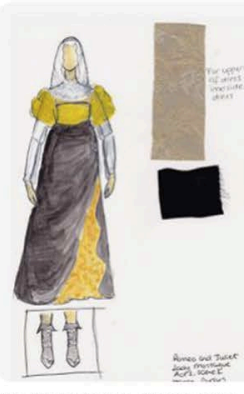

Costume design sketches for Costume design sk Romeo \& Juli

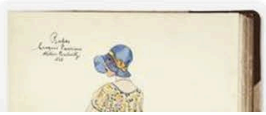

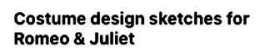
Romeo \& Juliet

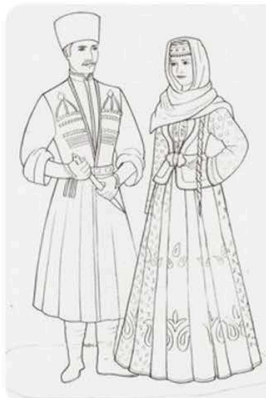

Старинный Кавказ в фотографиях - Кавказские...

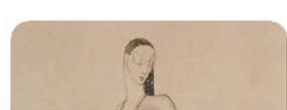

Costume design sketches for Romeo \& Juliet

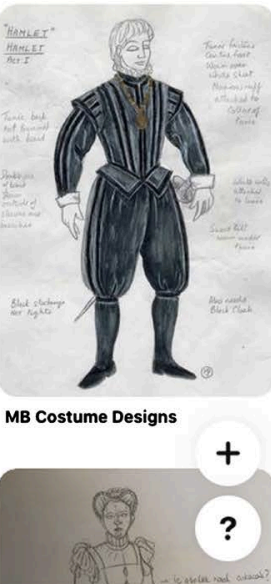

Figure 41. Example of the (S.F) Pinterest mood board (source by author). 
dinner and reused here (see Figure 43), I wanted it something with big horns made of hair. I got Merino wool (see Figure 44) for that, but it's diameter of a tube or something, roll it up made it into dreadlocks for the hair, and the mermaid tail is basically, it's a skirt, but it has a big tail on it (S.F).”

In addition (S.F) explained some details of mermaid costume stated:

"I would have to draw out what I thought a tail should look like and cut it out of paper. Have a look and see, do they want it longer? Stick it on the skirt pattern and think, okay, change the skirt patterns a bit. Other things you can do as well is use a dress stand" (S.F). However one of the important features of costume design process and technique is the costume look distinctive from a distance. They may have to contrast and build harmonies with other costume or textiles, to

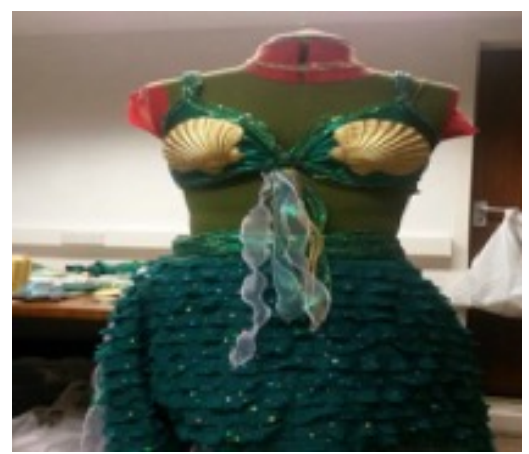

Figure 42. Mermaid costume (source by author).

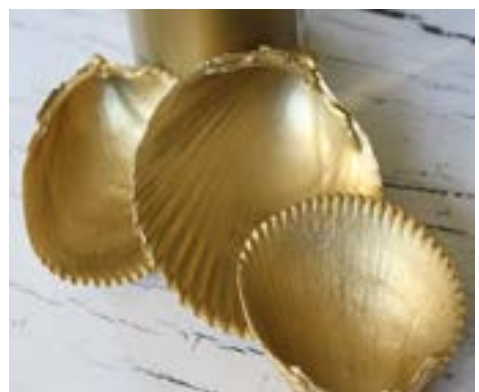

Figure 43. Example of reused dinner shells (Source by author).

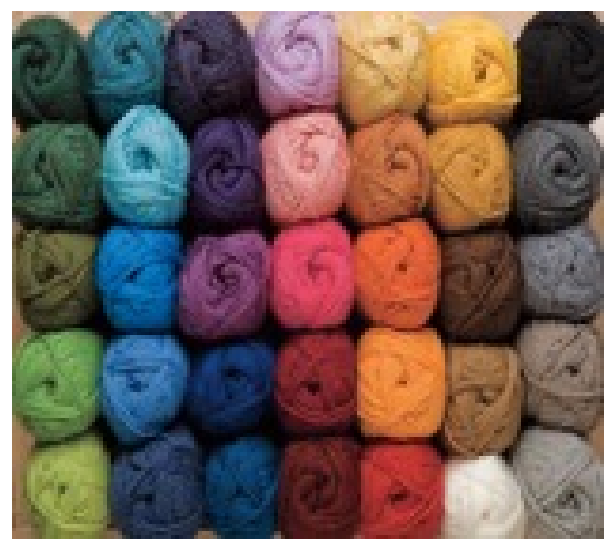

Figure 44. Mermaid hair made by Merino wool (source by author). 
achieve this it's need to used some broken down fabrickes left and decorated with some colors and matching them together to give the final look for the character on the stage (McArthur, Etchells, \& Shepard, 1997) the second costume are a draq queen character will show the secn challenges of the costumer during her costume design process to producing the costume.

\subsection{Costume 2: Drag Queen Gothic Character}

Another example of using and recycling costume and materials are for the Drag queen gothic character (see Figure 45), the costume designer (S.F) make Cotton bloomers short pants. Made from recycled white bed sheets found in the storage (see Figure 46) and the top blouse made of lace from old net curtain (see Figure 47), however the costume designer comment about reusing and recycling those textiles fabrics and materials stated: "You can always cut down fabrics and materiel and reused or recycled them aging for example as trousers. Still, trousers are really baggy so it's quite a lot of fabric there. It's possible you could remake them into a bag or something like that to put another costume in (S.F)."

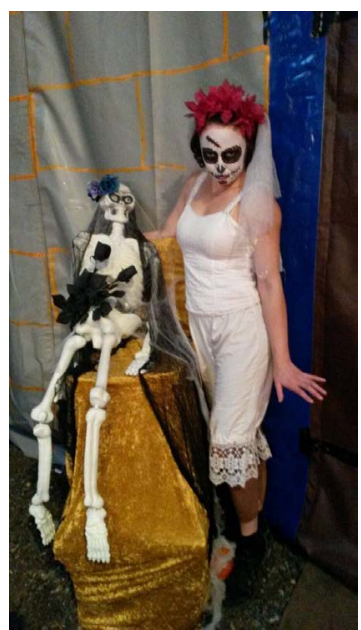

Figure 45. Drag queen gothic character; Cotton bloomers. Made from recycled white bed sheets with lace from old net curtain (source by author).

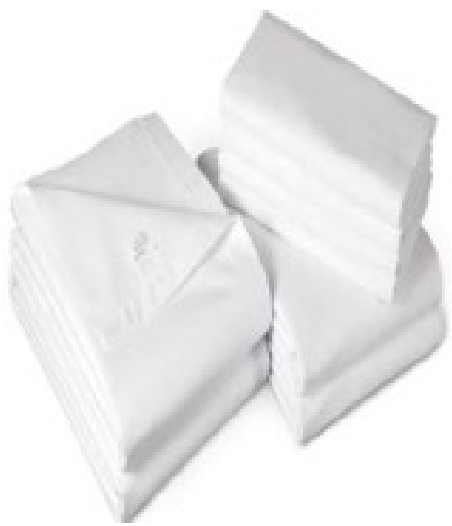

Figure 46. Example of white bed sheets was reused of the costume character (Source by author). 


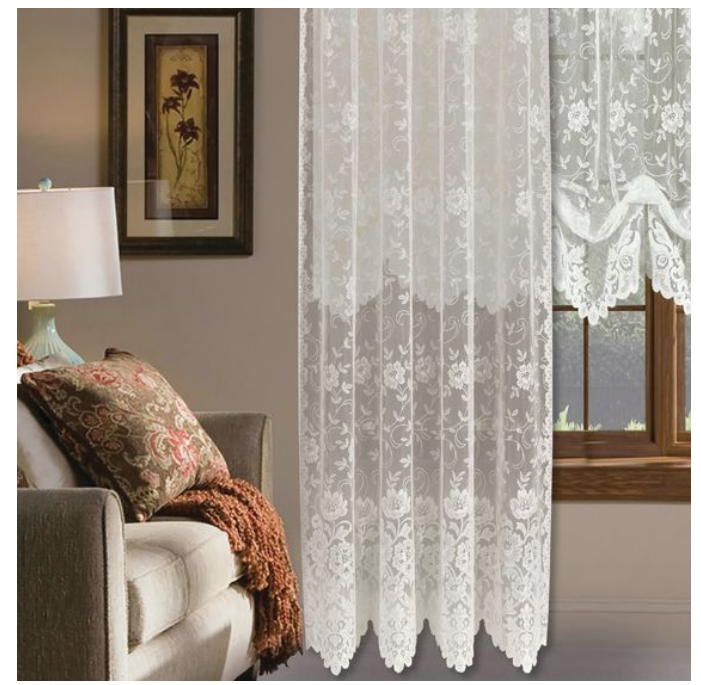

Figure 47. Example of old net curtain (source by author).

\subsection{Summary}

The costume (S.F) her costume design process and creating the costume shed alight her understanding of applying Lifecycle Assessment (LCA) (reused recycling)costume and materials in the process of producing costume, in addition, (Vezzoli \& Manzini, 2008) stated (reusing and recycling materials empowers the article of clothing originator to arrange for the impacts an item will have in terms of both input (the extraction of crude materials in pre-production) and output (the emissions and waste generated by the product during production, use and disposal).used an old home textiles from the theater storage from another play to her costume show very clearly that there are a possibilities to applying sustainable practice for the costume designer. However, the next play is a drama play observed one of the costume designer works in hear costume studio Liverpool city.

\section{Play 8: Marat/Sade}

\subsection{Background}

Marat/Sade is a gruesome depiction of class struggle and human suffering which questions whether true revolution comes from changing society or changing oneself, based on the play based in Charenton Asylum in France 1808 (see Figure 48 and Table 8), (Sherd, 2017) (L.S) for the play Marat/Sade (L.S) are costume maker and dresser based in Liverpool with involvement in design cutting fabric and development a garment from sustainable textiles materials, during the interview with (L.S) at her studio in Liverpool, was observed her work process of design and making the costume I was very interesting, to know which kind of method she usually use to designing and making costume $<$ are there any sustainable practice during her design, the costume designer (L.S) provide and showed me her costumes and work in her studio (costume drawing, costumes from the Marat/Sade play). 


\subsection{Costume Designer Process and Technique}

Each costumes designer has different techniques and independents process of designing the costumes (Monks, 2010) the process of the costume designer (L.S) are very interesting to deliver the characters then the costumes to the life stage stated:

"My process of designing costumes even for the Marat/Sade or any play, "I by and large begin off on collage disposition board and make loads of temperament sheets. And after that from the disposition sheets, go to plan gatherings and come to them with certain pictures, For occasion, in the event that I do begin with a script, I'll see at the diverse characters and attempt and discover bits of their identity that would reflect what they would wear and after that fair assemble a tremendous pool of investigate and information and make a disposition sheets of collage collection of pictures" (see Figure 49).

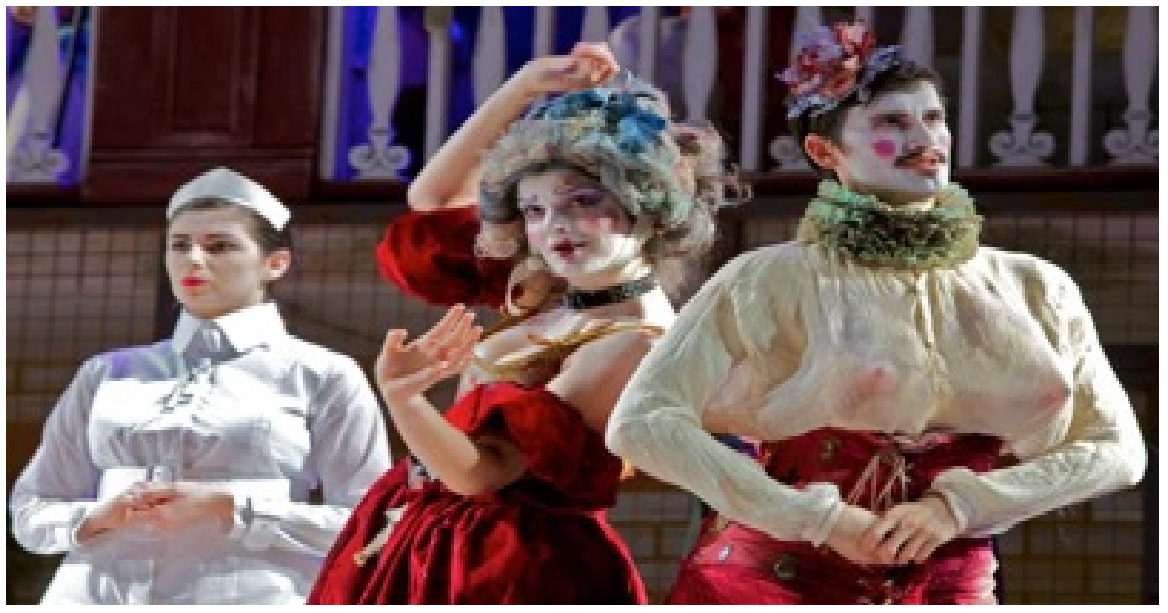

Figure 48. The poster for the play Marat/Sade.

Table 8. Details of the play project.

\begin{tabular}{ccc}
\hline Site & Play name & Data Collector \\
\hline Art Space Studio Liverpool & Marat/Sade & Author
\end{tabular}

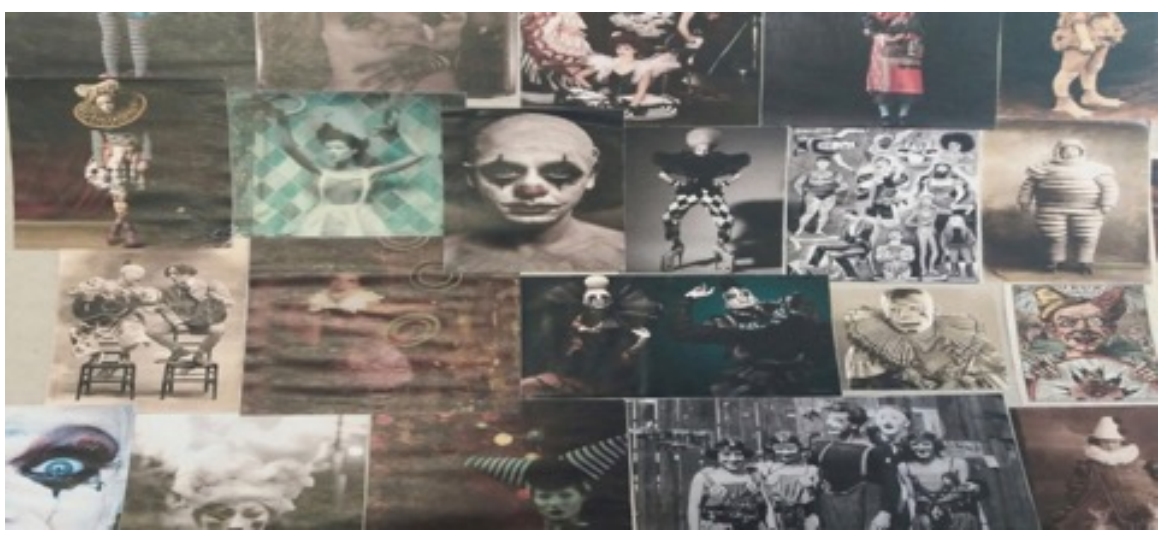

Figure 49. Mood boards of collage collection of images for the characters Marat/Sade. 
The costume designer (L.S) also comment while I am observing her work in hear studio, also apart from her process of design the costume are sketching and start developing the costumes until be confident with what some ideas come up with. Then drawing some proper designs out and then show those to the cast and the crew.

In addition, while I am in hear studio, I found a much variety of different figures of dolls with a variety of different textiles in another boxes, which lead me to ask to hear this question about the reason of Making figures of dolls? The costume designer (see Figure 50) (L.S) stated:

"This is additionally s portion of my planning handle, I making a characters dole's which it's offer assistance me to construct the vision of fabrics that will utilize conjointly to see the outfits characters in $3 \mathrm{~d}$ points of view, to know which textures materials, I utilized for each characters. I created the dolls whereas observing and while watching the inmates rehearse, making their person back stories and sicknesses empowering the creation of an ensemble suited to each personality".

However, Design and development a character's costumes is elements of the themes of the play, which is the figures will composition of the costume and character poses carry out the actions of and attitudes of the characters of any play (Ingham et al., 2003). This clear argument about the importance design the costume characters figures, to know the costume budget need, the number of textiles and fabrics for each character.

According to (Fletcher, 2008) comment that there are large number of designer their attitude focusing on textiles waste and management, and the costume designer (L.S) are one of large number of the costume designers ate the UK, who are focusing on textiles waste and management during her design process by using the dolls and selecting the finals textiles materials to avoiding waste a much of textiles.

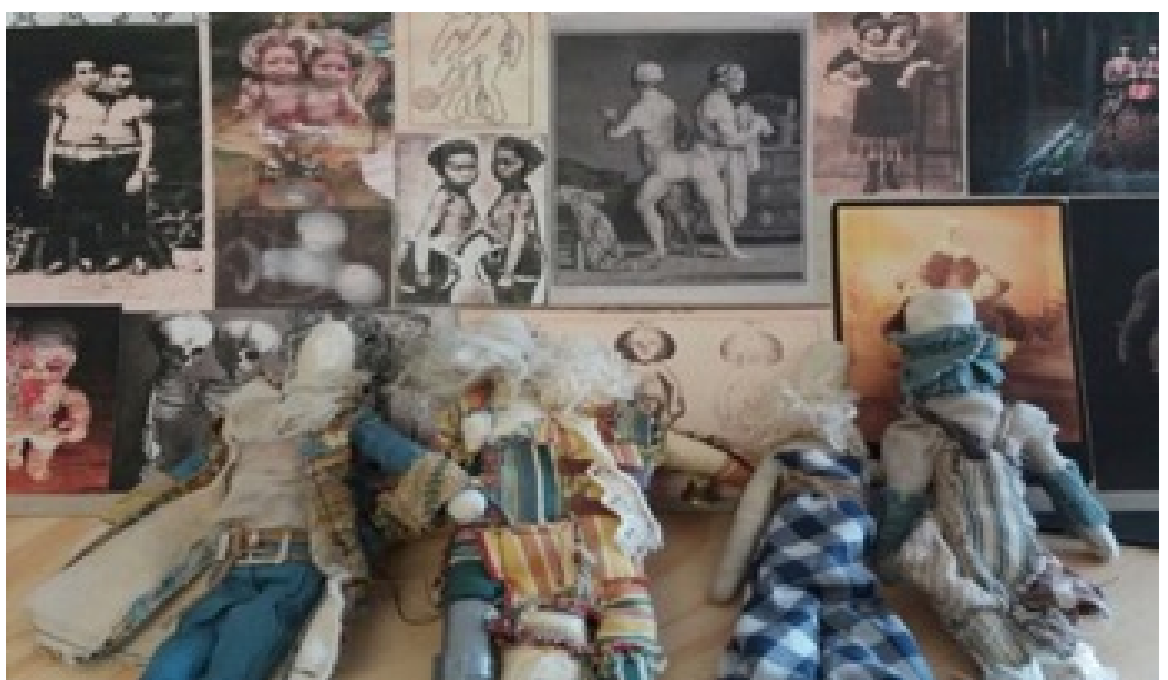

Figure 50. Marat/Sade dolls costumes characters (source by author). 


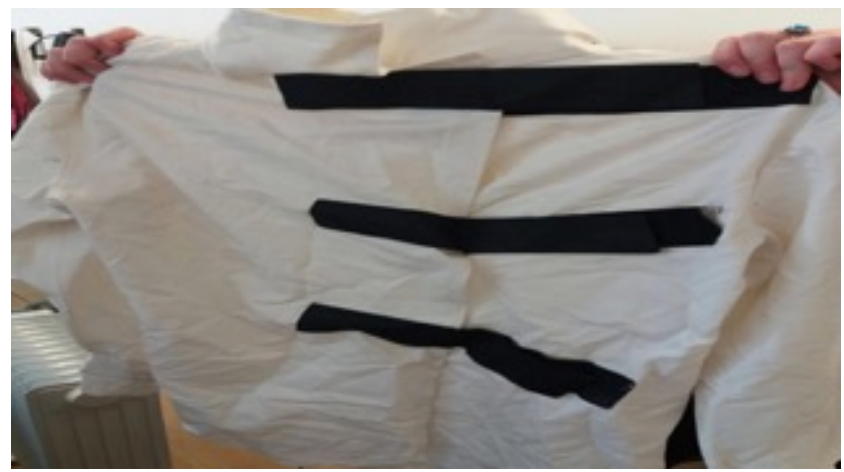

Figure 51. One of the jackets that found in the costume store was reuse it and recycled to one of the characters by (L.S).

\subsection{Various of Reusing and Recycling Costume and Textiles Technique}

The costume design process was very organic, (L.S) costume designer are very absorbing and focusing in produce mostly for all her costume project in more sustainable and organic ways, (L.S) comment about her sustainable methods of using organic materials during her general design process and for the Marat/Sade play comments:

"Most of the materials I do utilize for my work are more sustainable materials fair since I think it's more pleasant. Fair maintaining the environment, I think is very critical. You've have to be careful of anything you are doing in any career. Don't really buy, I used to work with polystyrene and things and I wouldn't work with that again just because it's just so bad for the planet so it's definitely important to keep that in mind (L.S)."

And while I am in her studio, I was very exiting the materials that was used to all the costume for the Marat/Sade play, I asked if there are any recycling and reusing process was used to making the costumes (L.S) comment:

"Yes. I do recycle all the textiles and reusing some costumes wherever possible and for Marat/Sade show, a lot of materials it was made out of existing things. I think my show came in under budget because I'd used so much stuff that already existed like using their costume store and then making things out of mop heads and making whole garments out of a series of just objects that I'd found. And I did another costume which was a white jacket with a black band (see Figure 51), the whole thing was made out of found materials. I bought nothing new for it even for this play and any costumes projects".

In addition the costume designer (L.S) given and shows me while in her studio in Liverpool a variety of different visual images, and provided for me as an evidence of a successful examples of her sustainable deign practice for the (Marat/Sade) play, showed me of the main costume character the costume whole body suit was made out of (hessian sacks) with three of reused waistcoat (see Figure 52, Figure 53) which used a hessian organic materials and added 


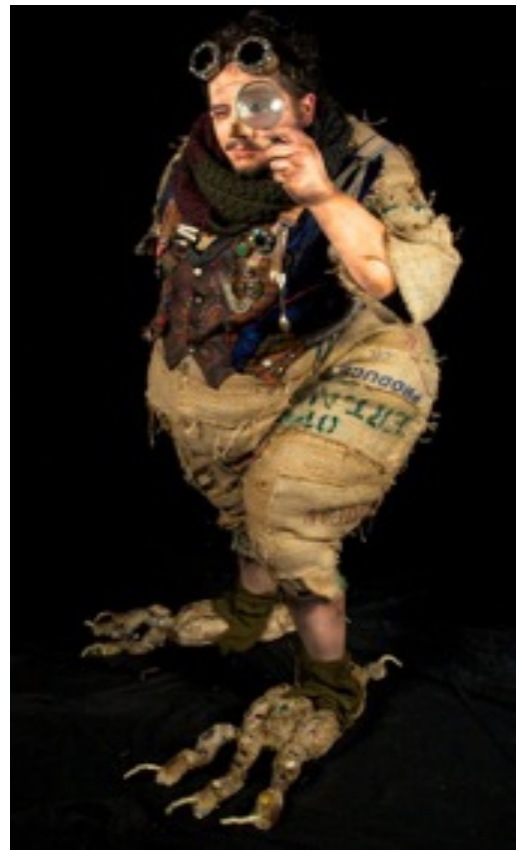

Figure 52. One of the main character designs reused and recycles hessian sacks with three waistcoats (Sherd, 2017).

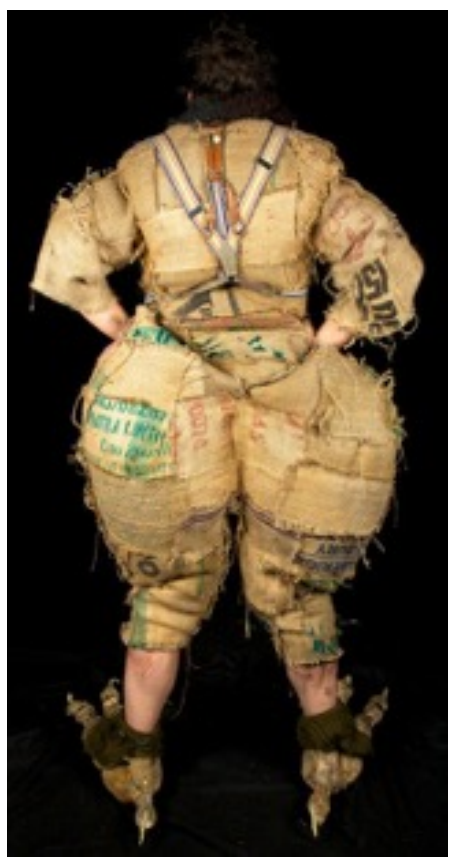

Figure 53. Another position of the character wearing a costume made of hessian sacks materials (Sherd, 2017).

collaged together (see Figure 54). (L.S) Comment about her sustainable designing practice process of selecting the materials and regarding for this character said:

"I really like that, and I do think it's really wasteful the way you can just buy something completely brand new then to just get throw it away straight 


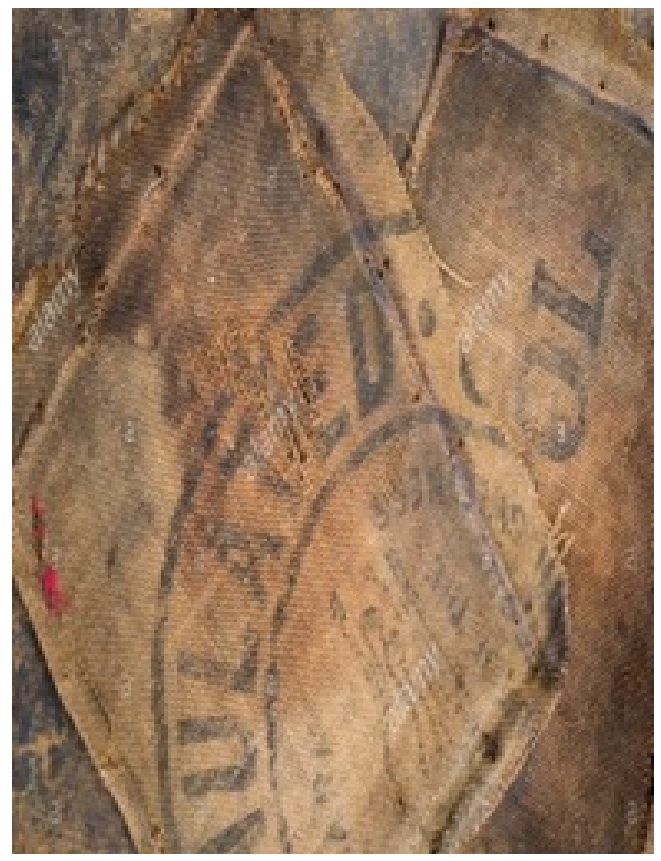

Figure 54. Example of the (hessian sacks material) (Sherd, 2017).

afterwards. I really don't see the point of that. Which is why I do generally always try to use things that already exist" In his book the practical guide to a greener theater (Jones et al., 2013) comment the "Sustainability is a journey of any production and applying a sustainable practice in the design journey are important step toward future advance".

According to (L.S) during our informal conversation at her studio that keeping a period outline grounded the generally stylish within the 1800s for the Marat/Sade play, but with the chaos and advanced references within the play a differing run of a reused $d$ materials were utilized. Such as the costume in figure (55) (L.S) was used the one of the most character wearing a recycled coat from reused old curtain fabrics textiles was found in the costume store, combining curtain with the made up of three vintage white coats and skirt and reused of the two of brown belts from the second hand vintage shop.

However the costume designer (L.S) her process of design and making the costume give a huge agreement proof evidence and argument for different anthers discussed about that Reusing and recycling squander texture could be a universally useful for making costumes and there's still awesome potential for development garments (costumes) (Mayer et al., 2014), because with appropriate care of the (garment, costumes) it is possible to prolong the costumes (garment) life time, Bring significant environment saving (Monks, 2010; Fletcher, 2008), by using different costume constriction and sustainable methods technique to transfer apices of costume to another costumes character.

At (L.S) studio while observing her work and I founded her small costume wardrobe, a costume for one of the main character in the play(Marat/Sade) the costume looking was to dirty look (see Figure 56, Figure 57) I asked her about 


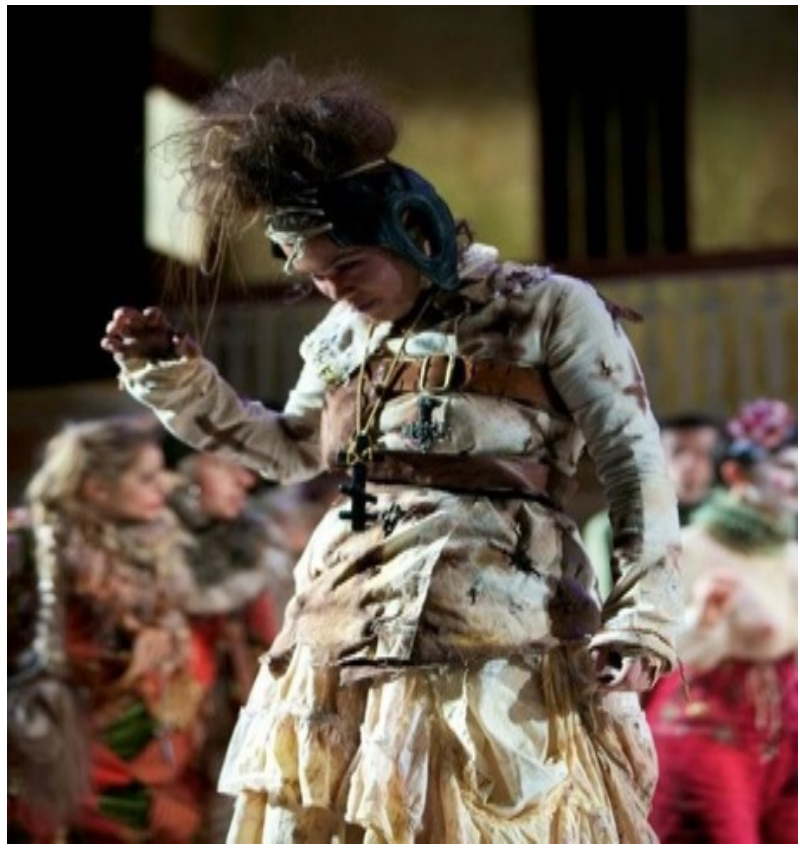

Figure 55. Variety of reused textiles materials (Sherd, 2017).

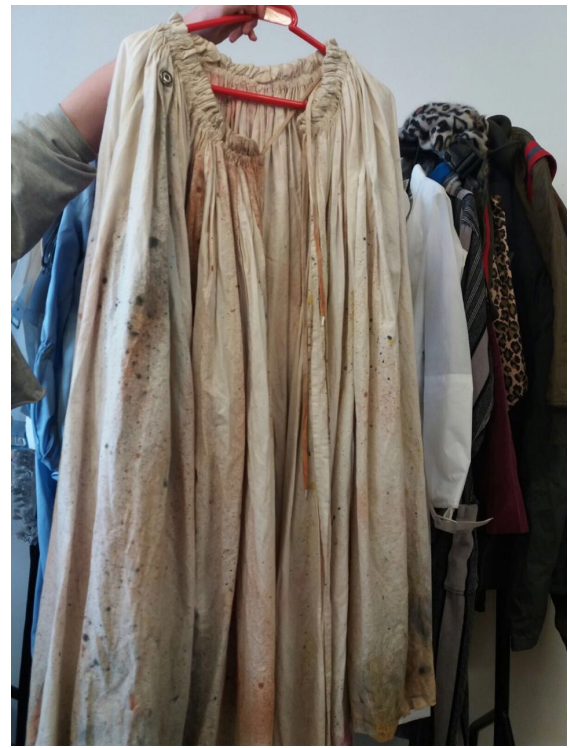

Figure 56. This costume was made from a reused fabric from the costume store (Sherd, 2017).

the techniques and the process of deign this costume, which kind of materials was used to made this costume:

"I do regularly develop a parcel of the articles of clothing, this ensemble are breaking down, employing a assortment of passing on and contracting textures method, to provide grimy search for one of this primary character identity was a mental clutter, I draws a few chaotic surfaces over the garment textures to inexact the tangible and visual picture of the most character identity on the organize" (see Figure 58). 


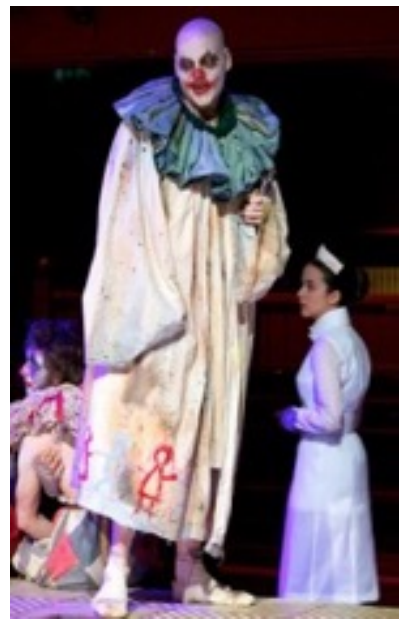

Figure 57. The main character wearing a costume was made a variety of reusing and recycled (Sherd, 2017).

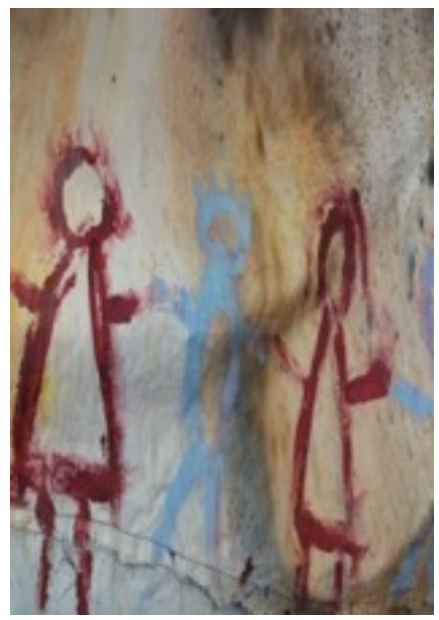

Figure 58. Drawing some painting and texture above the costume to give the real character personality look (Sherd, 2017).

\subsection{Summary}

However the (L.S) costume designer her techniques of mixing and matching existing pieces of textiles fabrics or a shredded some costume fabrics and used them again for another purposes of deign or for another costume, It's a part of apparel (garment, costume) Reusing and recycling process effort is concerned with recycling (Wang, 2006; Lambeth, 2017) the diagram below are sunrise the UK costume designer their process and skills of selecting costume materials for the production regarding for the 4 plays analysis.

Through these, I explored the variations among Kuwaiti layout and the Western world (represented with the aid of using the UK) and supplied critiques and guidelines on how sustainable design can be brought in Kuwait.

\section{Research Limitation}

Blind spots in gown layout questioning in addition to institutional boundaries 
make it not possible at gift to caricature a direction able to bringing Kuwait to the equal degree of sustainable costume design as the United Kingdom or different western countries. However, numerous suggestions may be made to assist Kuwaiti costumiers gain an extra stage of sustainability of their tactics to gown layout. I actually have recognized 4 key steps that may be taken. Based on training derived from the United Kingdom costumiers, in Table 9, I offer a listing of suggestions for a greater sustainable design technique primarily based totally at the 3Rs with the intention to assist Kuwaiti costumiers reuse/recycle costumes and substances in Kuwait theatre productions.

Table 9. A summary of recommendations.

\section{The route to sustainable costume design in Kuwaiti theatre}

1. The route to sustainable costume design in Kuwaiti theatre

2. Establish cloth dresser departments in principal Kuwaiti theatres

3. Proactively undertake UK strategies and wondering with regards to costume design

4. Reusing/Re-making repairing costumes and glued textiles Recycled Costumes Via (Reconstructing Techniques)

5. Encourage Kuwaiti costumiers to apply second-hand clothes in costume design

6. Educate and teach designers and tailors with inside the use of sustainable design and costume manufacturing methods.

\section{Conclusion}

The most conclusion of this paper inquire about is that important parties within the Kuwait theatre industry must centre, sometime recently anything else, on changing the basic shortage in information relating to reuse and reusing techniques in ensemble design. Typically, since, as things right now stand, there's no concept of support capacity within the minds of Kuwaiti costumiers, nor in those of tailors. The truth is that Kuwaiti costumiers have limited experience and information of reusing and reusing ensembles and materials implies they have openings within the future to address each step within the life cycle of an article of clothing (Payne, 2011). Not at all like the UK where nearly all theatres have closet divisions and those that don't can contract outfits from others or ensemble shops. Coupled with the need for consent for creators to keep the outfits they make, this implies that outfits are either binned, destroyed at that point binned, or essentially dumped in a landfill after appear is wrapped up.

\section{Conflicts of Interest}

The author declares no conflicts of interest regarding the publication of this paper.

\section{References}

Al-Arfaj Group (2015). Kuwait Waste Collection and Recycling Company.

Al-Ghareb, S. (1988). Theatrical Movement in Kuwait Documentation Pages (pp. 85-93). Office Politics Press. 
Al-Ghareb, S. (2001). The History of the Kuwaiti Theatre (pp. 120-133). Office Politics Press.

Al-Wgyan, K. (2010). Kuwait Theatre Culture (4th ed., pp. 272-288). Kuwait National office.

Andersen, K., \& Earley, R. (2014). Design Thinking for Sustainability. Mistrafuturefashion. 20th Annual International Sustainable Development Research Conference, Trondheim, 18-20 June 2014, 1-12.

http://mistrafuturefashion.com/wp-content/uploads/2015/12/D3.5b-Andersen Earley 2014.pdf

Anon (2016). May Contain Food. Luca Silvestrini’s PROTEIN. https://proteindance.co.uk/production/may-contain-food/

Blackburn, R. S. (Ed.) (2009). Sustainable Textiles: Life Cycle and Environmental Impact. Woodhead Publishing.

Clancy, D. (2014). Designing Costume for Stage and Screen. Pavilion Books.

Evans, K. (2015). Costume Construction. Waveland Press.

Fletcher, K. (2008). Sustainable Fashion and Textiles. Earthscan.

Gwilt, A. (2014). What Prevents People Repairing Clothes? An Investigation into Community-Based Approaches to Sustainable Product Service Systems for Clothing Repair. Making Futures Journal, 3, p 31. http://shura.shu.ac.uk/8125/1/Gwilt Alison.pdf

Gwilt, A., \& Rissanen, T. (2011). Shaping Sustainable Fashion. Taylor \& Francis. https://doi.org/10.4324/9780203126172

Ingham, R., Covey, L., \& Ingham, R. (2003). The Costume Technician's Handbook. Heinemann.

Jones, E., Pribble, J., Brunner, P., \& White, M. (2013). A Practical Guide to Greener Theatre: Introduce Sustainability into Your Productions. Taylor \& Francis Group. https://doi.org/10.4324/9780203555996

Lambeth, C. (2017). Creating the Character Costume: Tools, Tips, and Talks with Top Costumers and Cosplayers. Routledge. https://doi.org/10.4324/9781315746319

Mayer, V., Banks, M., \& Caldwell, J. (2014). Production Studies. Routledge.

McArthur, A., Carolyn, E., \& Tristram, S. (1997). Design and Make It! Textiles Technology. Nelson Thorne.

Monks, A. (2010). The Actor in Costume. Palgrave Macmillan.

Morgan, S. (2009). Waste, Recycling and Reuse. Evans Brothers.

Muthu, S. (2018). Sustainable Innovations in Recycled Textiles. Springer. https://doi.org/10.1007/978-981-10-8515-4

Naseem, K. (2013). Gend \& Aatch. Pavilion Books.

Payne, A. (2011). Frantic Fashion and Australia's Invisible Designers: Conversations on Sustainability in the Mass Market. Fashion Colloquium London, London, 21-22 September 2011, 13 p. (Unpublished).

Pollatsek, E., \& Wilson, M. (2017). Unbuttoned: The Art and Artists of Theatrical Costume Design. Routledge. https://doi.org/10.4324/9781315688084

Sherd, L. (2017). Liz Sheard. http://www.lizsheard.co.uk/

Vezzoli, C., \& Mezzini, E. (2008) Sustainable Fashion: Past, Present and Future. Library of Congress Catalog.

Wang, Y. E. (2006). Recycling in Textiles. CRC Press. 